Unger, G. M., H. Konrad and T. GebureK (2011): Does spatial genetic structure increase with altitude? An answer from Picea abies in Tyrol, Austria. Plant Syst Evol, 292: 133-141.

Varshney, R. K., A. Graner and M. E. Sorrells (2005): Genic microsatellite markers in plants: features and applications. Trends Biotechnol. 23: 48-55.

WANG, R., S. G. COMPTON and X. Y. CHEN (2011): Fragmentation can increase spatial genetic structure without decreasing pollen-mediated gene flow in a wind-pollinated tree. Mol Ecol 20: 4421-4432.

Wang, Y., J. Luo, X. Xue, H. Korpelainen and C. Li (2005): Diversity of microsatellite markers in the populations of Picea asperata originating from the mountains of China. Plant Sci 168: 707-714.

WRIGHT, S. (1931): Evolution in Mendelian populations. Genetics 16: 97-159.

Wu, J., K. V. KRUtovskil and S. H. Strauss (1998): Nuclear DNA diversity, population differentiation, and phylogenetic relationship in the California closed-cone pines based on RAPD and allozyme markers. Genome 42: 893-908.

YANG, F. S., Y. LI, X. I. N. Ding and X. Q. WANG (2008): Extensive population expansion of Pedicularis longi- flora (Orobanchaceae) on the Qinghai-Tibetan Plateau and its correlation with the Quatemary climate change. Mol Ecol 17(23): 5135-5145.

YEH, F. C., R. YANG and T. BoYle (1999): POPGENE VERSION 1.3.1. Microsoft Window-based free ware for population genetic analysis. University of Alberta Edmonton.

ZHANG, F. M. and S. Ge (2002): Data analysis in population genetics. I. analysis of RAPD data with AMOVA. Biodiversity Sci 10: 438-444.

ZHANG, Y. L., B. Y. LI and D. ZHENG (2002): A discussion on the boundary and area of the Tibetan Plateau in China. Geogr Res 21: 1-8.

Zhao, Z. J., L. Y. TAN, D. W. Kang, Q. J. LiU and J. Q. LI (2012): Responses of Picea likiangensis radial growth to climate change in the Small Zhongdian area of Yunnan Province, Southwest China. Chin J Appl Ecol 23: 603-609.

Zou, J. B., X. L. Peng, L. Li, J. Q. LiU, G. Miehe and L. Opgenoorth (2012): Molecular phylogeography and evolutionary history of Picea likiangensis in the Qinghai-Tibetan Plateau in ferred from mitochondrial and chloroplast DNA sequence variation. J Syst Evol 50 341-350.

\title{
Genetic analysis of European common ash (Fraxinus excelsior L.) populations affected by ash dieback
}

\author{
By B. Fussi ${ }^{1), *)}$ und M. KonNERT ${ }^{1)}$
}

(Received 24 $4^{\text {th }}$ March 2014)

\begin{abstract}
European common ash is an important component of mixed forest ecosystems in Bavaria and is considered a valuable tree species under climate change. The first aim of the present study was to assess the genetic diversity within and between ash populations in Bavaria in comparison with neighboring regions. Because ash stands have been heavily attacked by ash shoot disease in the last few years, the second aim of the study was to detect genetic differences between susceptible and less susceptible trees (trees with defoliation up to $30 \%$ ) within populations. Altogether 41 populations were investigated using nuclear and chloroplast microsatellites. The results showed high genetic variation within and high genetic differentiation between ash populations. Higher chloroplast microsatellite variation was detected instead populations from south-eastern Bavaria compared to other regions. The comparison of susceptible and less susceptible groups of individuals within each population
\end{abstract}

1) Bavarian Office for Forest Seeding and Planting, Forstamts platz 1, D-83317 Teisendorf.

*) Corresponding author: BARBARA Fussi. Tel. +49-86 66-98 83 44, Fax +49-86 66-98 83 30. E-Mail: Barbara.Fussi@asp.bayern.de revealed medium to high genetic differences in some cases. For the observed heterozygosity, higher values were found for the group of less susceptible trees compared to the group of all trees or to the group of susceptible trees within populations. This could be a first indication that individuals with a higher heterozygosity might be able to withstand ash dieback in a better way compared to homozygotic individuals. Within the group of less susceptible trees a relatively wide genetic base exists whereupon a future breeding programme can be built. Thus it is of utmost importance for the species to maintain less affected trees in order to keep the genetic potential for future adaptation processes within ash populations, seed production and regeneration.

Key words: Fraxinus excelsior, genetic diversity, Hymenoscyphus fraxineus, nuclear microsatellites, chloroplast microsatellites.

\section{Introduction}

European common ash (Fraxinus excelsior L.) is an important component of mixed forest ecosystems in Bavaria, representing a valuable native European noble hardwood species. Ash is less competitive compared to other broadleaves (e.g. beech) and can become a domi- 
nant species on sites connected to high groundwater levels and/or a high soil base saturation (KöLLING and WALENTOWSKI, 2002). In contrast to beech, ash has less dense crowns which allows other shade-tolerant species to form a more structured forest. Ash is considered a valuable tree species under climate change, because it can tolerate warm and dry conditions (KöLLING, 2007). Currently there are 155 certified seed stands for European common ash in Bavaria from which seeds were harvested regularly until the outbreak of ash dieback a few years ago, comparable to the dutch elm disease. Forestry now runs the risk of losing this economically and ecologically valuable tree species for mixed forests due to the increasingly severe ash dieback.

European ash (Fraxinus excelsior L.) is threatened by ash dieback, a disease caused by the fungus Hymenoscyphus fraxineus (BARAL et al., 2014), occurring first in Poland and meanwhile in most parts of Europe (PUKACKI and PRZYBYL, 2005; BAKYs et al., 2009a; WoODWARD and BOA, 2012; VASAITIS et al., 2013). The origin of the fungus was unknown until recently when it was proved to originate from East Asia, where it is a saprophytic fungus and plays a similar ecological role on $F$. manshurica as $H$. albidus on $F$. excelsior (VASAITIS et al., 2013; ZHAO et al., 2012). As a consequence of the increasing damage the research dealing with ash has also increased. The causative agent was identified in 2009 (KOWALSKI and HOLDENRIEDER, 2009; BAKYs et al., 2009b; QUELOZ et al., 2011) and methods to describe the disease stages in ash were developed later on (MCKINNEY et al., 2011a; LENZ et al., 2012a; METZLER et al., 2013). LENZ et al. (2012a) described the status and the distribution of the disease for Bavaria. Due to its successful dispersal and infectious strategy, $H$. fraxineus was able to rapidly establish itself on various sites. In 2009 on permanent study plots of the Bavarian State Institute of Forestry (LWF) only $9 \%$ of pole stage and $1 \%$ of mature forests were dead. In $201120 \%$ dead trees in pole stage forests and $2 \%$ of dead trees in mature forests were recorded (LENZ et al., 2012a).

After observing that some individuals were less affected by the disease than others systematic investigations on the resistance against the disease were started (McKinney et al., 2011a; PliURA et al., 2011; KJÆR et al., 2011; STENER, 2013). Such investigations include the question whether the lower susceptibility of certain individuals might be in relation to genetics. Several studies in ash exist using molecular markers on genetic structure (e.g. HöLtKEN et al., 2003; MORAND et al., 2002; HEUERTZ et al., 2001, 2003, 2004a, 2004b, 2006; HEBEL et al., 2006a, 2006b; FERrAZZINI et al., 2007; BACLES and ENNOS, 2008; SuTHERLAND et al., 2010; GÖMÖRY et al., 2012), others studies are dealing with gene flow and hybridization (e.g. FERNÁNDEZ-MANJARRÉS et al., 2006; Thomasset et al., 2013, 2014; GÉRARD et al., 2013). In Southern Germany one study on genetic variation of European ash focus on provenance regions (HEBEL et al., 2006b). The results generally revealed a high genetic variation within the analysed populations.

In Bavaria detailed information on genetic diversity of ash populations based on molecular markers have been lacking until now. The present paper assess the genetic diversity within and between ash populations from Bavaria (South Germany) in comparison to ash populations from other European countries with special emphasis on certified seed stands. Another aim of this study is to evaluate genetic differences between susceptible and less susceptible trees within populations, an aspect which had been completely overlooked. Due to the lack of resistance related markers for ash, selectively neutral ones (nuclear and chloroplast microsatellites) were used in the present study, as for other similar studies in the past (e.g. HöLTKEN et al., 2003; HeuERTz et al., 2004a, 2004b; HEBEL et al., 2006a, 2006b; FERRAZZINI et al., 2007; BACLES and ENNOs, 2008; GÖMÖRY et al., 2012).

\section{Material and Methods}

\section{Plant material}

The investigated ash populations comprise fourteen registered seed stands from Germany (German provenance regions 02, 04, 06, 07, 08), Austria and Slovenia, seventeen provenances from Germany, Switzerland and Romania in the provenance trial "Marxheim" (Bavaria) established in 1988 (Kleinschmit et al. 2002) and ten permanent study plots installed in 2010 by the Bavarian State Institute of Forestry (LWF) (Table 1). From the German and Austrian seed stands mixed seed samples were available and 96 seeds per provenance were analysed. From other populations, buds or cambium from individual trees were collected. The number of sampled trees is given in Table 2. Altogether the number of analyzed samples per population ranged from 20-100 for nuclear microsatellites (Table 2) and from 13-97 for chloroplast microsatellites (Table 3).

\section{DNA isolation}

DNA was extracted for all samples using the ATMAP method (Dumolin et al., 1995). Before extraction, embryos from seeds, buds (1 bud per tree) and cambium (tissue of $1 \mathrm{~cm}$ diameter) were lyophilized for 24 hours. DNA extracts were fluorometrically quantified (Gene Quant Pro, Amersham Bioscience) and adjusted to $20 \mathrm{ng} / \mathrm{\mu l}$.

\section{PCR amplification}

All populations were analysed at nuclear and chloroplast microsatellites using the Qiagen-multiplex-Kit for PCR.

\section{nSSR amplification}

Altogether 2358 individuals were genotyped at eight highly polymorphic nuclear microsatellite loci (LEFORT et al., 1999; BRACHET et al., 1999) combined into three multiplex PCRs (fluorescent labels of primers in brackets).

multiplex A: Femsatl10 (Cy5) + M2-30 (Dy751), concentration in primermix: $2 \mu \mathrm{M}$ each

multiplex B: Femsatl11 (Cy5) + Femsatl12bis (Dy751)

+ Femsatl19 (IRD700), concentration in primermix: $2 \mu \mathrm{M}$ each

multiplex C: Femsatl4 (Cy5) + Femsatl8 (Dy751) + Femsatl16 (IRD700), concentration in primermix: $1 \mu \mathrm{M}$ $+2 \mu \mathrm{M}+2 \mu \mathrm{M}$, respectively. 
Multiplex PCRs were performed using fluorescent labelled primers (concentrations of primers are given above) in a mixture of $10 \mu$ l total volume containing $1 \mathrm{X}$ reaction buffer (Qiagen) and about $20 \mathrm{ng}$ template DNA. The PCR program started with initial denaturation at $95^{\circ} \mathrm{C}$ for $15 \mathrm{~min}$, followed by 25 cycles of $94^{\circ} \mathrm{C}$ for $30 \mathrm{sec}$, $55^{\circ} \mathrm{C}$ for $90 \mathrm{sec}, 72^{\circ} \mathrm{C}$ for $30 \mathrm{sec}$ and a final elongation step at $60^{\circ} \mathrm{C}$ for $30 \mathrm{~min}$. The length of the PCR fragments was determined by using an automated sequencer (CEQ8000 Beckman-Coulter) and analysed by using an internal size standard. Fragment length determination and allele assignment were carried out using the fragment analysis tool of CEQ8000 (Beckman-Coulter).

\section{cpSSR amplification}

Altogether 2146 individuals were genotyped at five chloroplast microsatellite loci (WEISING and GARDNER, 1999) combined into one multiplex PCR.

multiplex D: ccmp2 (Cy5) + ccmp4 (Cy5) + ccmp6 $($ IRD700 $)+$ ccmp7 $($ Cy5 $)+$ ccmp10 $($ Cy5 $)$, concentration in primermix: $2 \mu \mathrm{M}+1 \mu \mathrm{M}+2 \mu \mathrm{M}+8 \mu \mathrm{M}+2 \mu \mathrm{M}$, respectively.

The multiplex PCR was performed using fluorescent labelled primers (concentrations of primers are given above) in a mixture of $10 \mu \mathrm{l}$ total volume containing $1 \mathrm{X}$ reaction buffer (Qiagen) and about $20 \mathrm{ng}$ template DNA. The PCR program started with initial denaturation at $95^{\circ} \mathrm{C}$ for $15 \mathrm{~min}$, followed by 25 cycles of $94^{\circ} \mathrm{C}$ for $30 \mathrm{sec}$, $57^{\circ} \mathrm{C}$ for $90 \mathrm{sec}, 72^{\circ} \mathrm{C}$ for $30 \mathrm{sec}$ and a final elongation step at $60^{\circ} \mathrm{C}$ for $30 \mathrm{~min}$. Fragment analysis was performed as for nuclear microsatellites.

\section{Data analysis}

Data analysis was performed separately for the three types of investigated populations (seed stands, provenance trial "Marxheim", permanent study plots (LWF)), because of different establishment histories of the populations (e.g. type of material used for the provenance trial).

\section{nSSR}

For nuclear microsatellites GenAlEx 6.41 (PEAKALL and Smouse, 2006) was used to calculate the genetic parameters for each population: $\mathrm{N}_{\mathrm{A}}$ for the mean number of alleles, $\mathrm{N}_{\mathrm{R}}$ for the mean number of rare alleles per population with frequencies below $5 \%, \mathrm{~N}_{\mathrm{P}}$ for the mean number of private alleles occurring only in one of the populations, genetic diversity $\mathrm{N}_{\mathrm{E}}$ for the effective number of alleles (BROWN and WEIR, 1983), observed heterozygosity $\mathrm{H}_{\mathrm{O}}$ (HARTL and CLARK, 1997) and expected heterozygosity $\mathrm{H}_{\mathrm{E}}$ (HARTL and CLARK, 1997). In order to compare the number of alleles independent of sample size, allelic richness (A) was calculated with rarefaction using the software FSTAT (GOUDET, 1995), thereby the calculation is based on the smallest number of individuals typed in a population and given as the mean over all loci.

The software GenAlEx 6.41 (PeAKALL and Smouse, 2006) was also used to estimate the pairwise genetic distance between all provenances following NEI (1972). The software FSTAT (GOUDET, 1995) was used to calculate overall $\mathrm{F}_{\mathrm{IS}}$ and genetic differentiation by overall and pairwise $\mathrm{F}_{\mathrm{ST}}$ values (Weir and Cockerham, 1984). Additionally a Bayesian approach (STRUCTURE, FALUSH et al., 2003) was used to identify structuring for the fourteen seed harvesting stands and the seventeen provenances of the provenance trial. The analysis parameters were set to 20.000 runs in the burn-in period, then 20.000 iterations, under the admixture model. $\mathrm{K}$ was set to 1-15 for the seed harvesting stand analysis and to 1-20 for the provenance trial analysis with 10 iterations per K for both. The highest "delta K" corresponds to the uppermost level of hierarchy among runs with $\mathrm{K}=1-15$ and $K=1-20$ based on the rate of change between successive $K$ values (EvanNo et al., 2005). The means of the probabilities $(\operatorname{Ln}(\mathrm{K}))$ of the genetic data over the 10 replicated runs and their standard deviations plotted against the number of estimated clusters were used in order to choose the most likely number of clusters. Thereby the $\mathrm{K}$-value with the highest mean value together with the lowest standard deviation was selected.

\section{cpSSR}

For chloroplast microsatellites, again GenAlEx 6.41 (PEAKAll and Smouse, 2006) was used to calculate genetic parameters. Based on haplotypes defined for each sample the following parameters of genetic variation were calculated: $\mathrm{N}_{\mathrm{A}}$ for the mean number of variants, genetic diversity $\mathrm{N}_{\mathrm{E}}$ for the number of effective alleles (BROWN and WEIR, 1983) and the haploid genetic diversity $\mathrm{h}$ for the probability that two individuals are different (SCHNEIDER et al., 1997).

Genetic differentiation between populations was again calculated with GenAlEx 6.1 (PeAKall and SMouse, 2006) using Nei's genetic distance (NEI, 1972) and visualized for the seed stands by constructing an unrooted Neighbor-Joining tree using PHYLIP (FELSENSTEIN, 2004).

\section{Comparison of susceptible versus less susceptible trees}

A comparison of susceptible versus less susceptible trees in relation to $H$. fraxineus attack was performed within the provenance trial and the permanent study plots. The goal was to see if the used neutral markers were able to detect genetic differences between the damaged and the undamaged subpopulation within a provenance/plot, but also to verify if the surviving individuals are genetically constricted or not. This is important for future breeding strategies.

Damage was recorded for the sampled trees following the classification scale elaborated by LENZ et al. (2012b). Each tree was classified into one of six classes starting from class 0 for trees with no symptoms to class 5 with $100 \%$ damage. Classes $0-1$ (trees with no symptoms or with little damage and up to $30 \%$ lack of crown foliage) were then combined into one group called "less susceptible". Classes 2-5 were combined into another group called "susceptible". In a first step genetic parameters were compared between all trees per population and the less susceptible trees. The rationale behind this was to estimate/predict changes in genetic parameters of future 
ash populations. These calulations should give a picture of populations affected by ash shoot disease before and after the selection of the trees through the disease. The results should give an impression of the genetic parameters of the remaining populations after the susceptible trees have died and are not available for future reproduction. In a second step susceptible trees were compared to less susceptible ones for each population in order to detect the genetic difference between the two collectives.

The software GenAlEx 6.41 (PeAKAlL and SMouse, 2006) was used to calculate $\mathrm{N}_{\mathrm{A}}$ for the mean number of alleles, genetic diversity $\mathrm{N}_{\mathrm{E}}$ for the effective number of alleles (BROWN and WEIR, 1983) and observed $\left(\mathrm{H}_{\mathrm{O}}\right)$ and expected $\left(\mathrm{H}_{\mathrm{E}}\right)$ heterozygosity (HARTL and CLARK, 1997) for each group. Additionally allelic richness (A, values given after rarefaction) and heterozygote deficit $\left(\mathrm{F}_{\text {IS }}\right)$ was calculated in FSTAT (GOUDET, 1995). Relatedness of individuals for both groups (susceptible vs. less susceptible) within populations was calculated according to Queller and Goodnight (1989) in GenAlEx 6.41 (PeAKall and Smouse, 2006). Because some studies found high heritabilities of resistance against ash shoot disease (e.g. STENER et al., 2013), we wanted to find out, if relatedness between less susceptible trees within populations was higher compared to the relatedness between susceptible trees. The mean of the pairwise relatedness values for each group is given. For each value the differences between susceptible and less susceptible groups were tested for significance using a Mann-Whitney Test in R (R CORE TEAM, 2013).

Genetic differentiation between groups within populations was quantified using pairwise Nei's genetic distances (NEI, 1972) in GenAlEx 6.41 (PEAKALL and Smouse, 2006) and pairwise $\mathrm{F}_{\mathrm{ST}_{\mathrm{T}}}$-values (tested for significance) in FSTAT (GOUDET, 1995).

Finally all susceptible versus all less susceptible individuals were pooled into two groups and differences in genetic diversity parameters (allelic richness A, observed heterozygosity $\mathrm{H}_{\mathrm{O}}$, genetic diversity $\mathrm{H}_{\mathrm{S}}$, heterozygote deficit within $\left(\mathrm{F}_{\mathrm{IS}}\right)$ and among $\left(\mathrm{F}_{\mathrm{ST}}\right)$ populations) including tests of significance were calculated in FSTAT (GOUDET, 1995).

\section{Results}

Genetic diversity

Results based on nSSR-markers

Altogether 338 alleles were detected at eight nuclear microsatellite loci. The lowest variation was shown by the locus Femsatl16 with 15 alleles, whereas locus Femsatl10 exhibited the highest variation with 73 alleles. Distribution of alleles within populations varied considerably with often 2-3 highly frequent alleles (>20\%-40\%). Within seed stands Slovenian populations (SLO-Brezje, SLO-Konjiska gora) and one Austrian population (AUT-Karnerviertel) had low numbers of rare alleles (72, 48 and 80 respectively), whereas other populations (e.g. D-Ostholstein_02, D-Plantage_04, D-Hochstift_04, and AUT-Ettenau) carry between 137 and 146 rare alleles (data not shown).
Because of different establishment histories of the three types of investigated populations the results were compared separately for seed stands, the provenance trial "Marxheim" and the permanent study plots (LWF) presented in Table 2. For seed stands, the mean number of alleles per locus $\left(\mathrm{N}_{\mathrm{A}}\right)$ varied between 11.4 (SLO-Konjiska gora) and 24.1 (AUT-Ettenau). Similar large differences between populations were found for the mean values of rare alleles $\left(\mathrm{N}_{\mathrm{R}}\right)$ varying from 6.1 (SLO-Konjiska gora) to 18.3 (AUT-Ettenau). For 12 out of 14 stands unique alleles $\left(\mathrm{N}_{\mathrm{P}}\right)$ were detected which are missing in all other populations. The highest values for such private alleles were found in D-Kempten_07 (mean of 0.8). Genetic diversity $\left(\mathrm{N}_{\mathrm{E}}\right)$ varied between 5.4 (AUT-Karnerviertel) and 10.9 (AUT-Ettenau), allelic richness (A) was between 9.5 (AUT-Karnerviertel) and 14.1 (AUTEttenau). Values for the observed heterozygosity $\left(\mathrm{H}_{\mathrm{O}}\right)$ was found in the medium range (0.694-0.768), values for expected heterozygosity $\left(\mathrm{H}_{\mathrm{E}}\right)$ were slightly higher (0.750-0.856).

The number of alleles $\left(\mathrm{N}_{\mathrm{A}}\right)$ of the populations within the provenance trial varied between 11.5 (D-Lichtenfels) and 16.8 (D-Scheßlitz). Both the differences and the values are thereby slightly lower compared to the seed harvesting stands. A similar trend was found for the number of rare alleles $\left(\mathrm{N}_{\mathrm{R}}\right)$. Private alleles $\left(\mathrm{N}_{\mathrm{P}}\right)$ were found in eight out of seventeen analysed populations, pointing to the lower sample number compared to the seed stands and to the fact that for a provenance trial only a fraction of the natural population is present. Noteworthy is the high proportion of private alleles $\left(\mathrm{N}_{\mathrm{P}}\right)$ in the Romanian provenance "RO-Botosani" (mean of 0.8 ) of only 28 analysed individuals. This refers to a considerable difference of the eastern-European provenance compared to the Central European ones. The genetic diversity $\left(\mathrm{N}_{\mathrm{E}}\right)$ ranged between 5.4 (D-Kelheim) and 7.9 (D-Scheßlitz). Thereby the provenances exhibit relatively consistent values without pronounced extremes. The allelic richness (A) ranged from 9.1 (D-Lichtenfels, D-Kehlheim) to 12.9 (D-Scheßlitz). The observed heterozygosity $\left(\mathrm{H}_{\mathrm{O}}\right)$ values were found in the medium range (0.687-0.806), whereas the values for the expected heterozygosity $\left(\mathrm{H}_{\mathrm{E}}\right)$ were slightly higher, but less variable (0.771-0.844).

Within the ten permanent study plots the number of alleles $\left(\mathrm{N}_{\mathrm{A}}\right)$ ranged from 6.3 (D-Freising-I) to 22.3 (DFreising-II). The differences between certain populations were high and partly dependent on the different sample numbers. Remarkably low values were found for the stand "D-Freising-I". Only one stand (D-Coburg) reached the number of alleles $\left(\mathrm{N}_{\mathrm{A}}\right)$ of the seed stands. On seven out of ten plots we found private alleles $\left(\mathrm{N}_{\mathrm{P}}\right)$. Genetic diversity $\left(\mathrm{N}_{\mathrm{E}}\right)$ varied between 3.8 (D-Freising-I) and 9.0 (D-Freising-III). Allelic richness (A) ranged from 5.4 (D-Freising-I) to 14.6 (D-Töging-I). The observed heterozygosity $\left(\mathrm{H}_{\mathrm{O}}\right)$ was again in the medium range (0.644-0.796). Values for the expected heterozygosity $\left(\mathrm{H}_{\mathrm{E}}\right)$ varied between 0.657 (D-Freising-I) and $0.853(\mathrm{D}$ Freising-III).

Over all populations no regional patterns regarding the magnitude of the genetic variation were found. 
Table 1. - Description of 41 populations of European ash (Fraxinus excelsior) including the type of plant material sampled. Numbers following the population names of the seed stands correspond to the provenance region for common ash in Germany.

\begin{tabular}{|c|c|c|c|}
\hline Population & Country & $\begin{array}{c}\text { Type of } \\
\text { investigated } \\
\text { populations }\end{array}$ & Plant material \\
\hline $\begin{array}{l}\text { D-Adelsheim_07 } \\
\text { D-Ileuweg_06 } \\
\text { D-Kempten_07 } \\
\text { D-Kempten_08 } \\
\text { D-Landsberg_07 } \\
\text { D-Traunstein_08 } \\
\text { D-Wcißenhorn_07 } \\
\text { D-Ostholstein_02 } \\
\text { D-Plantage_04 } \\
\text { D-Hochslifi_04 } \\
\text { AUT-Etlenau } \\
\text { AUT-Karnerviertel } \\
\text { SLO-Brezje } \\
\text { SLO-Konjiska gora }\end{array}$ & $\begin{array}{l}\text { Germany } \\
\text { Germany } \\
\text { Germany } \\
\text { Germany } \\
\text { Germany } \\
\text { Germany } \\
\text { Germany } \\
\text { Germany } \\
\text { Germany } \\
\text { Germany } \\
\text { Austria } \\
\text { Austria } \\
\text { Slovenia } \\
\text { Slovenia } \\
\end{array}$ & Seed stands & $\begin{array}{l}\text { Mixed seeds } \\
\text { Mixed seeds } \\
\text { Mixed seeds } \\
\text { Mixed seeds } \\
\text { Mixed seeds } \\
\text { Mixed seeds } \\
\text { Mixed seeds } \\
\text { Mixed seeds } \\
\text { Mixed seeds } \\
\text { Mixed sceds } \\
\text { Mixed seeds } \\
\text { Mixed seeds } \\
\text { Buds } \\
\text { Buds } \\
\end{array}$ \\
\hline $\begin{array}{l}\text { D-Wertheim } \\
\text { D-Dillingen } \\
\text { D-Feuchtwangen } \\
\text { D-Kelheim } \\
\text { D- I ichtenfels } \\
\text { D-Mellrichstadt } \\
\text { D-Scheßlitz } \\
\text { D-Treuchtlingen } \\
\text { D-Weißenhorn } \\
\text { D-Sinntal } \\
\text { D-Bovenden } \\
\text { D-Walkenried } \\
\text { D-Wienhausen } \\
\text { D-Lehnsahn } \\
\text { CH-Aargau-Möhlin } \\
\text { CH-Aargau-Muri } \\
\text { RO-Bolosani }\end{array}$ & $\begin{array}{l}\text { Germany } \\
\text { Germany } \\
\text { Germany } \\
\text { Germany } \\
\text { Germany } \\
\text { Germany } \\
\text { Germany } \\
\text { Germany } \\
\text { Germany } \\
\text { Germany } \\
\text { Germany } \\
\text { Germany } \\
\text { Germany } \\
\text { Germany } \\
\text { Switzerland } \\
\text { Switzerland } \\
\text { Romania } \\
\end{array}$ & $\begin{array}{l}\text { P'rovenance trial } \\
\text { "Marxheim"" }\end{array}$ & Buds and cambium \\
\hline $\begin{array}{l}\text { D-Coburg } \\
\text { D-Freising-I } \\
\text { D-Freising-II } \\
\text { D-Freising-III } \\
\text { D-Röthelbach } \\
\text { D-Schweinfurt-I } \\
\text { D-Schweinfurt-II } \\
\text { D-Töging-I } \\
\text { D-Töging-II } \\
\text { D-Töging-III }\end{array}$ & Germany & $\begin{array}{l}\text { Permanent study } \\
\text { plots (LWF) }\end{array}$ & Buds and cambium \\
\hline
\end{tabular}

Results based on cpSSR markers (haplotypic diversity)

The average number of alleles within populations $\left(\mathrm{N}_{\mathrm{A}}\right)$ ranged from 1.0 (many populations) to 2.0 (D-FreisingII), with the mean of 1.2 (Table 3). Genetic diversity $\left(\mathrm{N}_{\mathrm{E}}\right)$ has comparable values between 1.0 (several populations) and 1.7 (D-Töging-I). Moreover, the values for haploid genetic diversity (h) varied between 0 and 0.321 (D-Töging-I), with a mean of 0.054 .

A clear relationship between certain regions and diversity parameters was not detected. Sixteen populations over all three types of investigated populations were monomorphic for the analysed chloroplast microsatellite loci. Few populations stood out with high diversity values (e.g. haploid diversity), among them D-Töging-I and II, D-Freising-II, D-Scheßlitz and one Austrian population (AUT-Ettenau).

\section{Genetic differentiation}

Based on nSSR markers

For the seed stands the genetic distance (NEI, 1972) varied between 0.10 (D-Traunstein_08 to AUT-Ettenau) and 0.35 (D-Hochstift_04 to AUT-Karnerviertel). Within the provenance trial the genetic distance values between provenances were higher with values between 0.18 (CH-Aargau-Muri to D-Dillingen) and 0.71 (D-Sinntal to D-Kelheim). For permanent study plots, values between 
0.14 (D-Töging-I to D-Töging-II) and 0.63 (D-Röthelbach to D-Freising-I) were calculated (data not shown).

Overall $\mathrm{F}_{\mathrm{IS}}$-values were 0.108 for all 41 populations and 0.112 for the German populations. Differentiation (overall $\mathrm{F}_{\mathrm{ST}}$ ) between all 41 populations was similar to the differentiation between all 34 German populations $\left(\mathrm{F}_{\mathrm{ST}}=0.046, \mathrm{p}<0.01\right.$ and $\mathrm{F}_{\mathrm{ST}}=0.045, \mathrm{p}<0.001$, respectively). Pairwise $\mathrm{F}_{\mathrm{ST}}$ values ranged from 0,005 (D-Töging-I to D-Schweinfurt-I) to 0,145 (D-Freising-I to
D-Röthelbach) for the permanent study plots. In the provenance trial the $\mathrm{F}_{\mathrm{ST}}$-values varied between 0,025 (D-Scheßlitz to D-Treuchtlingen) and 0,117 (D-Sinntal to D-Kelheim). The ash seed stands showed values from 0,008 (AUT-Ettenau to SLO-Brezje) to 0,072 (AUT-Karnerviertel to SLO-Konjiska gora) (data not shown).

Bayesian statistics revealed that for the seed harvesting stands the highest peak for delta $\mathrm{K}$ was found at $\mathrm{K}=2$, delineating only one population from Southern

Table 2. - Genetic parameters for 41 populations of Fraxinus excelsior based on eight nuclear microsatellite loci.

\begin{tabular}{|c|c|c|c|c|c|c|c|c|}
\hline Population & $\mathbf{N}$ & $\mathbf{N}_{\mathrm{A}}$ & $\mathbf{N}_{R}$ & $\mathbf{N}_{\mathbf{p}}$ & $\mathbf{N}_{1:}$ & $\mathbf{A}$ & $\mathbf{H}_{0}$ & $\mathrm{H}_{\mathrm{r}}$ \\
\hline D)-Adelsheim_07 & 96 & 21.1 & 15.5 & 0.0 & 8.7 & 12.4 & 0.727 & 0.835 \\
\hline D-Hcuwcg_06 & 96 & 20.6 & 14.8 & 0.1 & 9.0 & 12.5 & 0.716 & 0.827 \\
\hline D-Kcmpten_07 & 95 & 20.6 & 14.5 & 0.8 & 8.3 & 11.9 & 0.696 & 0.818 \\
\hline D-Kempten_08 & 93 & 19.0 & 12.5 & 0.1 & 8.4 & 12.0 & 0.723 & 0.804 \\
\hline D-Landslserg_07 & 96 & 22.4 & 16.4 & 0.3 & 9.4 & 12.6 & 0.748 & 0.840 \\
\hline D-'Traunstein_08 & 95 & 20.4 & 14.4 & 0.3 & 8.4 & 12.0 & 0.736 & 0.835 \\
\hline D-Weißenlhhorn_07 & 96 & 20.8 & 15.1 & 0.1 & 8.0 & 12.1 & 0.732 & 0.831 \\
\hline D-Ostholstein_02 & 96 & 23.6 & 17.5 & 0.3 & 10.7 & 13.9 & 0.715 & 0.856 \\
\hline D-Plantage_04 & 96 & 22.4 & 17.1 & 0.3 & 8.2 & 12.5 & 0.695 & 0.843 \\
\hline D-Hochstift_04 & 96 & 22.9 & 17.1 & 0.1 & 8.6 & 12.7 & 0.765 & 0.842 \\
\hline AU'T-Ettenau & 96 & 24.1 & 18.3 & 0.4 & 10.9 & 14.1 & 0.768 & 0.850 \\
\hline AU'I-Karnerviertel & 94 & 15.3 & 10.0 & 0.0 & 5.4 & 9.5 & 0.694 & 0.750 \\
\hline SLO-Brezje & 32 & 15.8 & 9.6 & 0.1 & 8.7 & 13.1 & 0.750 & 0.838 \\
\hline SIL-Konjiska gora & 31 & 11.4 & 6.1 & 0.1 & 6.3 & 9.6 & 0.743 & 0.769 \\
\hline D-Werthein & 38 & 13.5 & 7.3 & 0.1 & 6.4 & 10.2 & 0.687 & 0.784 \\
\hline D-Dillingen & 37 & 14.5 & 7.8 & 0.0 & 7.5 & 11.4 & 0.690 & 0.778 \\
\hline D-Fcuchtwangen & 33 & 13.0 & 7.6 & 0.3 & 6.5 & 10.6 & 0.744 & 0.803 \\
\hline D-Kelheim & 44 & 119 & 6.4 & 0.1 & 5.4 & 9.1 & 0.725 & 0.774 \\
\hline D-Lichtenfels & 40 & 11.5 & 5.4 & 0.0 & 5.9 & 9.1 & 0.726 & 0.787 \\
\hline D-Mellrichstadt & $3]$ & 12.6 & 6.9 & 0.0 & 7.5 & 10.5 & 0.806 & 0.844 \\
\hline D-Schelilitz & 36 & 16.8 & 11.0 & 0.1 & 7.9 & 12.9 & 0.703 & $0.8] 6$ \\
\hline D-Treuchtlingen & 38 & 13.9 & 7.5 & 0.0 & 7.5 & 10.8 & 0.746 & 0.830 \\
\hline D-Weikenhorn & 42 & 12.5 & 7.1 & 0.0 & 5.8 & 9.7 & 0.763 & 0.810 \\
\hline D-Sinntal & 35 & 13.8 & 89 & 0.0 & 5.8 & 10.6 & 0.715 & 0.771 \\
\hline D-Bovenden & 41 & 15.4 & 10.0 & 0.1 & 6.2 & 11.0 & 0.742 & 0.783 \\
\hline D-Walkenried & 39 & 13.1 & 7.5 & 0.0 & 5.9 & 9.8 & 0.771 & 0.798 \\
\hline D-Wienhauselı & 39 & 11.8 & 5.8 & 0.0 & 6.3 & 9.5 & 0.746 & 0.818 \\
\hline D-Lehnsahn & 39 & 13.1 & 6.5 & 0.0 & 6.6 & 10.3 & 0.703 & 0.814 \\
\hline CH-Aargau-Möhlin & 40 & 13.9 & 7.1 & 0.1 & 7.3 & 10.7 & 0.757 & 0.802 \\
\hline CH-Aargau-Muri & 43 & 15.3 & 10.0 & 0.1 & 7.4 & 11.5 & 0.772 & 0.782 \\
\hline RO-Botosani & 28 & 12.9 & 6.8 & 0.8 & 6.9 & 11.0 & 0.702 & 0.795 \\
\hline D-Coburg & 99 & 21.5 & 18.1 & 0.4 & 4.6 & 10.5 & 0.737 & 0.721 \\
\hline D-Freising-I & 37 & 6.3 & 2.0 & 0.0 & 3.8 & 5.4 & 0.796 & 0.657 \\
\hline D-Freising-II & 100 & 22.3 & 16.9 & 0.5 & 7.6 & 12.1 & 0.728 & 0.807 \\
\hline D-Freising-III & 76 & 20.4 & 14.5 & 0.3 & 9.0 & 12.7 & 0.724 & 0.853 \\
\hline D-Röthelbaclı & 51 & 13.5 & 8.3 & 0.1 & 5.4 & 9.7 & 0.701 & 0.789 \\
\hline D-Schweinfurt-I & 24 & 15.1 & 10.4 & 0.3 & 7.8 & 13.6 & 0.719 & 0.832 \\
\hline D-Schweinfurt-II & 31 & 14.5 & 8.1 & 0.0 & 7.6 & 12.2 & 0.644 & 0.797 \\
\hline D-Töging-I & 20 & 15.3 & 7.3 & 0.1 & 8.8 & 14.6 & 0.790 & 0.846 \\
\hline D-Töging-II & 49 & 18.3 & 12.8 & 0.1 & 7.5 & 12.3 & 0.735 & 0.813 \\
\hline D-'Töging-11I & 20 & 12.3 & 4.0 & 0.0 & 7.8 & 119 & 0.783 & 0.819 \\
\hline Mean & 57.5 & 16.3 & 10.5 & 6.4 & 7.4 & 14.6 & 0.733 & 0.806 \\
\hline
\end{tabular}

$\mathrm{N}$, number of individuals; $\mathrm{N}_{\mathrm{A}}$, mean number of alleles; $\mathrm{N}_{\mathrm{R}}$, rare alleles (frequency $<5 \%$ ); $\mathrm{N}_{\mathrm{P}}$, private alleles, $\mathrm{N}_{\mathrm{E}}$, genetic diversity as the number of effective alleles; (A), allelic richness after rarefaction (rarefaction size $=18) ; \mathrm{H}_{\mathrm{O}}$, observed heterozygosity; $\mathrm{H}_{\mathrm{E}}$, expected heterozygosity. 
Table 3. - Genetic parameters for 41 European ash populations based on five chloroplast microsatellite loci.

\begin{tabular}{|c|c|c|c|c|}
\hline Population & $\mathbf{N}$ & $\mathbf{N}_{A}$ & $\mathbf{N}_{\mathbf{E}}$ & h \\
\hline I)-Adelsheim_07 & 82 & 1.2 & 1.0 & 0.035 \\
\hline D-Hcuweg_07 & 93 & 1.6 & 1.2 & 0.138 \\
\hline D-Kempten_07 & 96 & 1.0 & 1.0 & 0.000 \\
\hline D-Kcmpten_08 & 85 & 1.2 & 1.0 & 0,005 \\
\hline D-Landslserg_07 & 94 & 1.2 & 1.0 & 0.012 \\
\hline D-'Traunstein_08 & 92 & 1.0 & 1.0 & 0.000 \\
\hline D-Weißenhorn_07 & 87 & 1.0 & 1.0 & 0.000 \\
\hline D-Ostholstein_02 & 96 & 1.4 & 1.1 & 0.060 \\
\hline D-Plantage_04 & 92 & 1.0 & 1.0 & 0.000 \\
\hline D-Hochstift_04 & 95 & 1.0 & 1.0 & 0000 \\
\hline AUT-Ettcnau & 4.3 & 1.6 & 1.6 & 0.287 \\
\hline AUT-Karnervicrtel & 1.3 & 10 & 1.0 & 0000 \\
\hline SLO-Brezje & 30 & 1.2 & 1.0 & 0.013 \\
\hline SLO-Konjiska gora & 29 & 1.0 & 1.0 & 0.000 \\
\hline D-Wertheim & 37 & 1.0 & 1.0 & 0.000 \\
\hline D-Dillingen & 35 & 1.0 & 1.0 & 0.000 \\
\hline D-Feuchtwangen & 31 & 1.0 & 1.0 & 0.000 \\
\hline D-Kelheim & 43 & 1.6 & 1.1 & 0.053 \\
\hline D-Lichtenfels & 37 & 1.2 & 1.0 & 0.020 \\
\hline D-Mcllrichsladt & 29 & 1.2 & 1.0 & 0.037 \\
\hline D-Scheßlitz & 36 & 1.8 & 1.4 & 0.235 \\
\hline D-Treuchtlingen & 38 & 1.2 & 1.0 & 0.011 \\
\hline D-Weilenhorn & 41 & 1.6 & 1,0 & 0.030 \\
\hline D-Sinntal & 35 & 1.0 & 1.0 & 0.000 \\
\hline D-Bovenden & 42 & 1.2 & 1.0 & 0.009 \\
\hline D-Walkenried & 34 & 1.2 & 1.0 & 0.034 \\
\hline D-Wienhausen & 39 & 1.0 & 1.0 & 0.000 \\
\hline D-Ichnsahn & 38 & 1.2 & 1.0 & 0.029 \\
\hline CH-Aargau-Möhlin & 40 & 1.0 & 1.0 & 0.000 \\
\hline CH-Aargau-Muri & 37 & 1.2 & 1.0 & 0.011 \\
\hline RO-Botosani & 28 & 1.0 & 1.0 & 0.000 \\
\hline D-Coburg & 97 & 1.2 & 1.0 & 0.020 \\
\hline D-Freising-I & 38 & 1.0 & 1.0 & 0.000 \\
\hline D-Freising-II & 88 & 2.0 & 1,4 & 0.229 \\
\hline D-Freising-III & 78 & 1.2 & 1.2 & 0.099 \\
\hline D-Röthelbach & 52 & 1.0 & 1.0 & 0.000 \\
\hline D-Schweinfurt-I & 25 & 1.4 & 1.0 & 0.033 \\
\hline D-Schweinfurt-II & 33 & 1.4 & 1.4 & 0.194 \\
\hline D-Tröging-I & 19 & 1.8 & 1.7 & 0.321 \\
\hline D-Töging-II & 49 & 1.8 & 1.4 & 0.238 \\
\hline D-Töging-III & 20 & 1.2 & 1.1 & 0.064 \\
\hline Mean & 52.3 & 1.2 & 1.1 & 0.054 \\
\hline
\end{tabular}

$\mathrm{N}$, number of individuals; $\mathrm{N}_{\mathrm{A}}$, mean number of alleles; $\mathrm{N}_{\mathrm{E}}$, genetic diversity as the number of effective alleles; $h$, haploid genetic diversity.

Austria (AUT-Karnerviertel) from the rest. Therefore for further interpretations the second most likely number of clusters $(\mathrm{K}=13)$ (Figure 1a) was considered. For the provenance trial the optimal number of genetic clusters was found to be 17 (Figure 1b). Also the means of the probabilities of the genetic data supported the selection of the mentioned clusters, because they were highest for the chosen K-values and had low standard deviation (Fig. $1 c$ and $1 d$ ).

Subsequently clusters at the population level were visualised for the seed stands and provenance trial separately (Figure 2 and 3, respectively). Populations showed strong differences in proportions of each cluster referring to differences between populations. Notewor- 


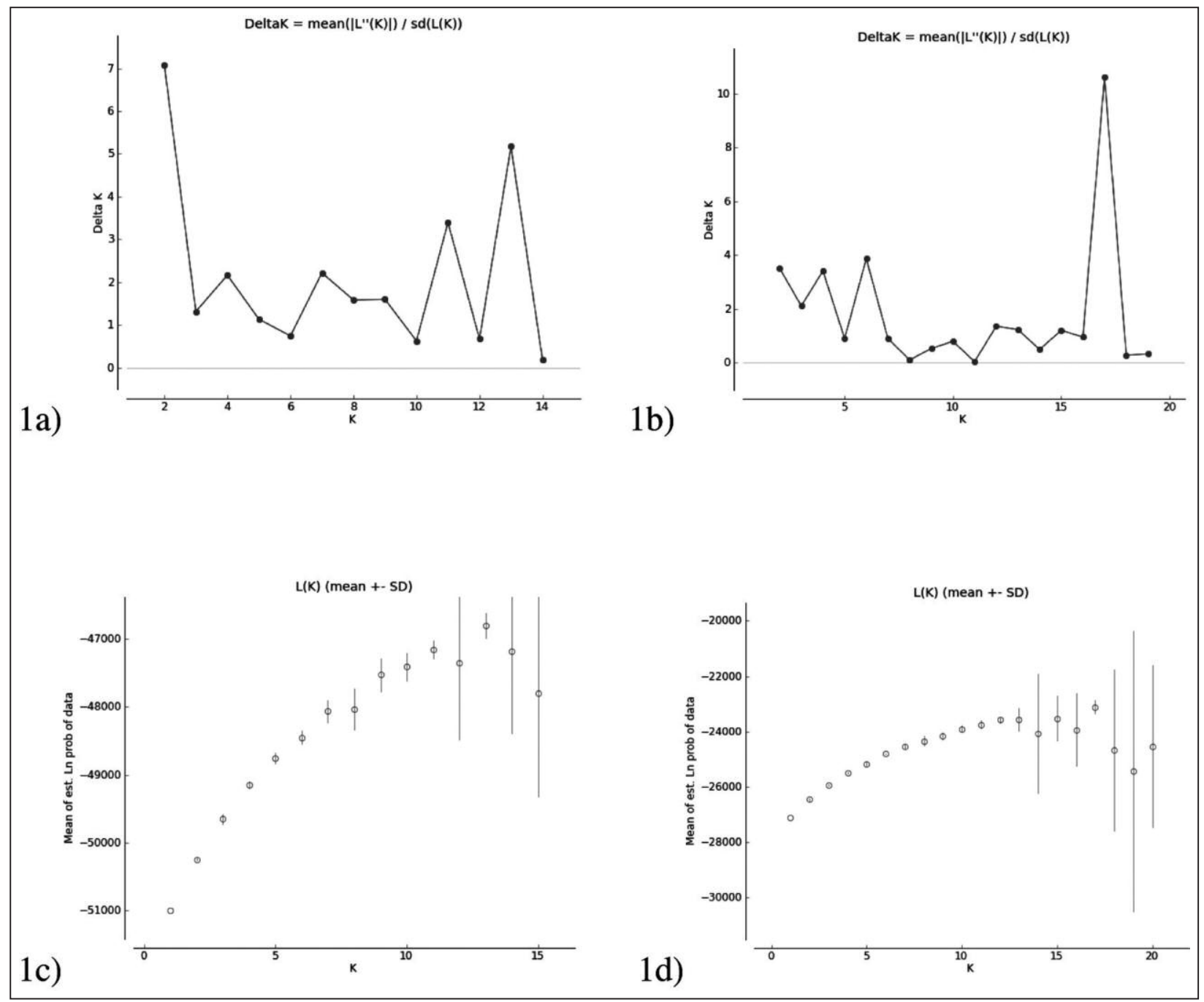

Figure 1. - Values for delta K1a) for the seed harvesting stands and b) the provenance trial; means of the probabilities of the genetic data over the 10 replicated runs and their standard deviations plotted against the number of estimated clusters $\mathrm{K}$ for the analyses of 1c) 14 ash seed harvesting stands and 1d) 17 provenances of the provenance trial "Marxheim" based on nuclear microsatellite data.

thy, in most of the cases each population had a specific high proportion cluster differing between populations.

\section{Based on cpSSR}

Because of the more conservative behaviour of the chloroplast markers, they are more likely to be suited for detecting large-scale regional patterns. As an example in Figure 4 the relationship of populations was visualized for the seed harvesting stands in a dendrogram. One group of populations was clearly distinguishable in the western part of Bavaria comprising the populations D-Kempten_07, D-Kempten_08, D-Weißenhorn_07 und D-Landsberg_07. More eastern distributed populations with D-Heuweg_06, D-Traunstein_08 and AUT-Ettenau formed a second group, which carried the allele "98" at locus "ccmp10". More southerly distributed populations from Austria and Slovenia (AUT-Karnerviertel, SLOBrezje and SLO-Konjiska gora) were again distinguished from the mentioned groups, but all other Ger- man populations resided within this group as well. Thus based on the analysed chloroplast markers, differentiation was detected for populations from Southwest Germany, but clear differences between populations from north and south of the Alps were not found.

\section{Genetic variation of susceptible versus less susceptible tree collectives}

These calculations were performed for populations of the provenance trial and the permanent study plots.

In a first step a comparison of the genetic variation between all trees and the less susceptible trees within populations was made (for sample numbers of each group see Table 2 and 4, respectively).

The mean number of alleles $\left(\mathrm{N}_{\mathrm{A}}\right)$ ranged from $6.3(\mathrm{D}$ Freising-I) to 22.3 (D-Freising-II) considering all trees per population (Table 2) and from 4.6 (D-Freising-I) to 19.4 (D-Coburg) in the group of less susceptible trees 
(data not shown). The values were lower in all populations in the group of less susceptible trees (Mann-Whitney-test; $\mathrm{p}<0.01$ ).

Genetic diversity $\left(\mathrm{N}_{\mathrm{E}}\right)$ ranged from 3.8 (D-Freising-I) to 9.0 (D-Freising-III) in all trees per population and from 3.4 (D-Freising-I) to 7.6 (D-Schweinfurt-I) in the group of less susceptible trees (Figure 5) and decreased in 22 out of 26 populations (data not shown) (MannWhitney-test; $\mathrm{p}<0.01$ ).

The calculation of allelic richness was based on 5 samples and ranged from 3.9 to 6.7 considering the whole populations and from 3.9 to 6.3 in the fraction of less

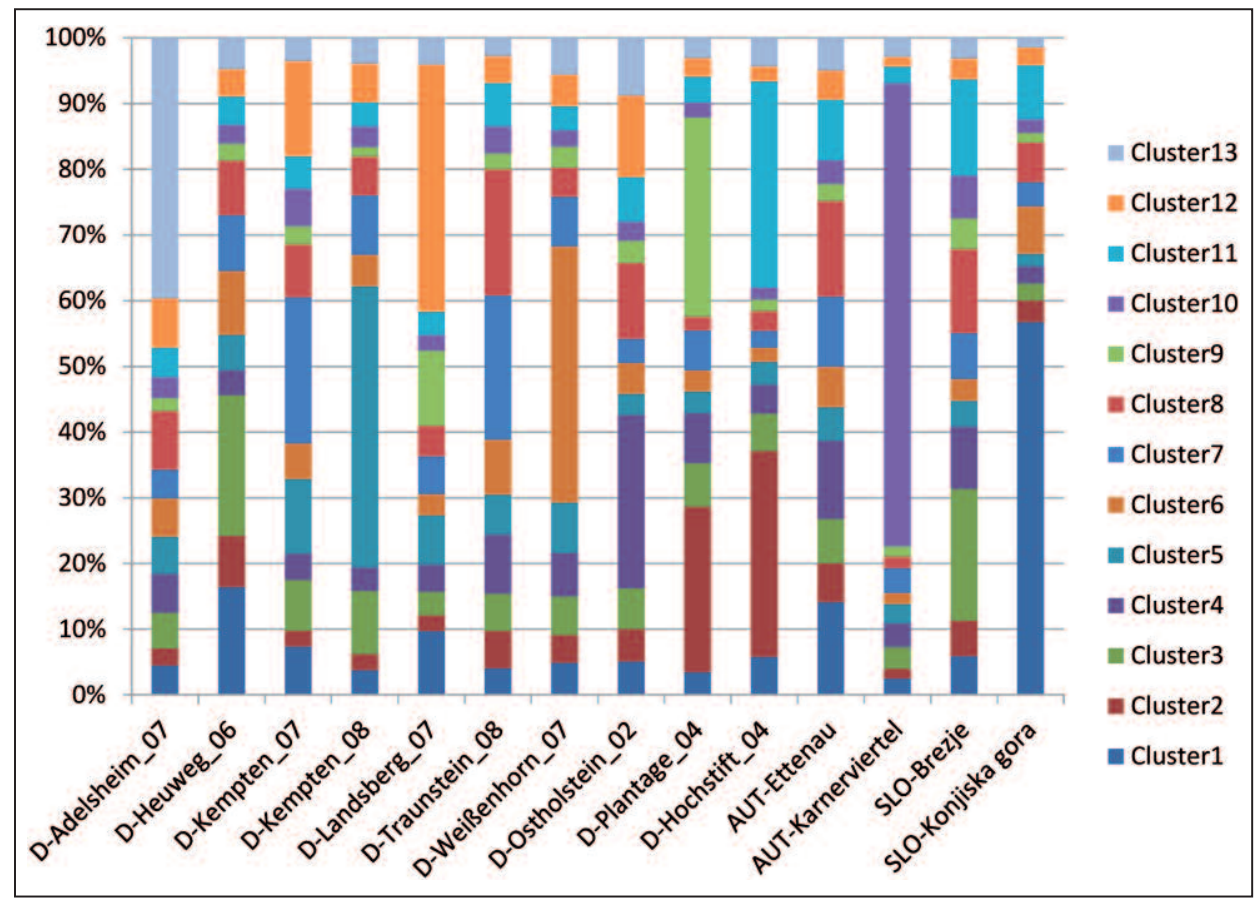

Figure 2. - Frequency diagram of clusters of 14 ash seed harvesting stands based on nuclear microsatellite data; bars representing the 14 populations and colors representing 13 clusters.

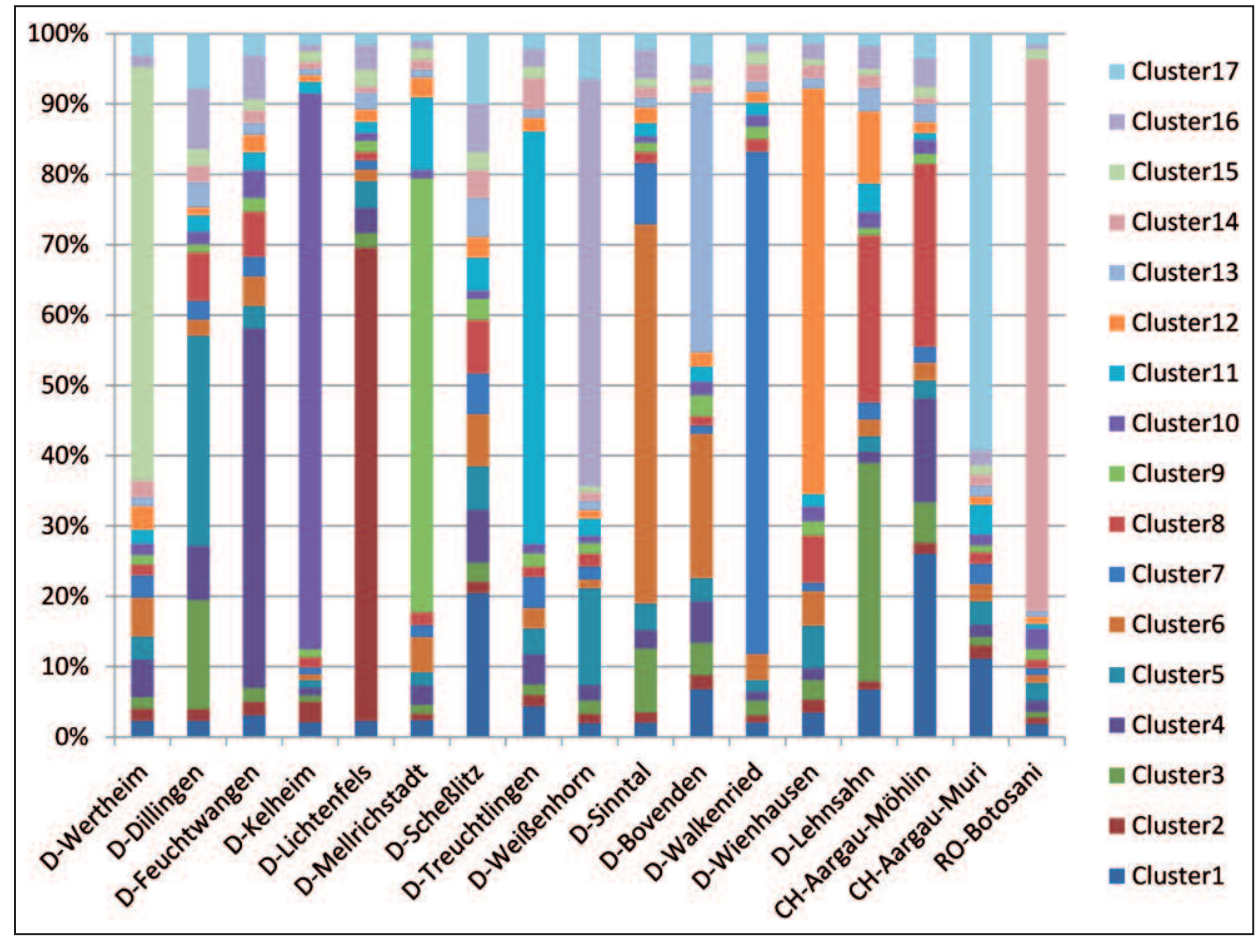

Figure 3. - Frequency diagram of clusters of 17 provenances of the provenance trial "Marxheim" based on nuclear microsatellite data; bars representing the 17 provenances and colors representing 17 clusters. 


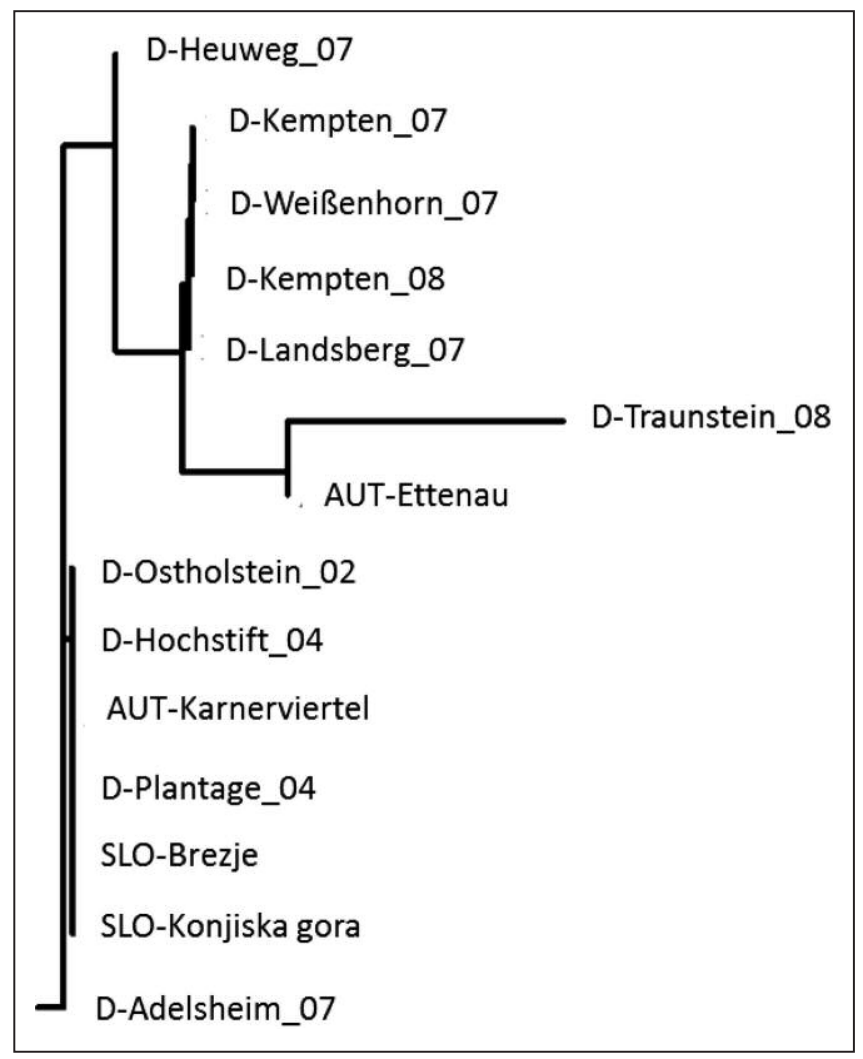

Figure 4. - Clustering of seed harvesting stands (NeighborJoining tree) based on the genetic distance following NEI (1972) using chloroplast microsatellites.

susceptible trees. The differences between all trees and less susceptible trees per population were not significant (Mann-Whitney-test, $\mathrm{p}=0.6$ ).

When comparing observed heterozygosity $\left(\mathrm{H}_{\mathrm{O}}\right)$ between all trees per population $\left(\mathrm{H}_{\mathrm{O}}\right.$ total $)$ and the less susceptible trees per population $\left(\mathrm{H}_{\mathrm{O}}\right.$ less susceptible) the values increased slightly in two thirds of the prove- nances (Figure 6). The results were not significant (Mann-Whitney-test, $\mathrm{p}=0.8$ ) but a trend was visible.

In a second step genetic differences between susceptible and less susceptible individuals were evaluated by calculating several genetic diversity parameters (Table 4). Population "D-Schweinfurt-I" was omitted in this step, because all observed individuals were classified as "less susceptible", as ash dieback was not detected in the year of assessment.

Genetic diversity ranged from 3.66 (D-Freising-I) to 9.04 (D-Freising-III) for the susceptible groups and from 3.41 (D-Freising-I) to 7.68 (D-Töging-II) for the less susceptible group. Thirteen populations showed higher values for genetic diversity in the less susceptible compared to the susceptible groups and for the other 13 populations the situation was the opposite.

Allelic richness varied between 3.95 (D-Freising-I) and 5.91 (D-Töging-I) for the susceptible groups and between 3.63 (D-Freising-I) and 5.5 (D-Freising-II) for the less susceptible group. In 15 populations allelic richness was higher in the less susceptible groups, in 11 populations the group of susceptible trees showed higher values for allelic richness.

Observed heterozygosity ranged from 0.643 (DScheßlitz) to 0.810 (D-Melrichstadt) for the groups of susceptible trees and from 0.643 (D-Schweinfurt-II) to 0.847 (D-Treuchtlingen) for the less susceptible ones. Eighteen populations showed higher values for the less susceptible trees.

Expected heterozygosity varied between 0.647 (DFreising-I) and 0.850 (D-Freising-III) in the susceptible groups and between 0.636 (D-Freising-I) and 0.830 (DTöging-II) in the less susceptible groups. This value was higher in 11 populations and lower in 15 populations for the less susceptible compared to the susceptible groups.

$\mathrm{F}_{\text {IS }}$-values ranged from -0.201 (D-Freising-I) to 0.229 (D-Scheßlitz) in the groups of susceptible trees and from -0.229 (D-Freising-I) to 0.206 (D-Schweinfurt-II)

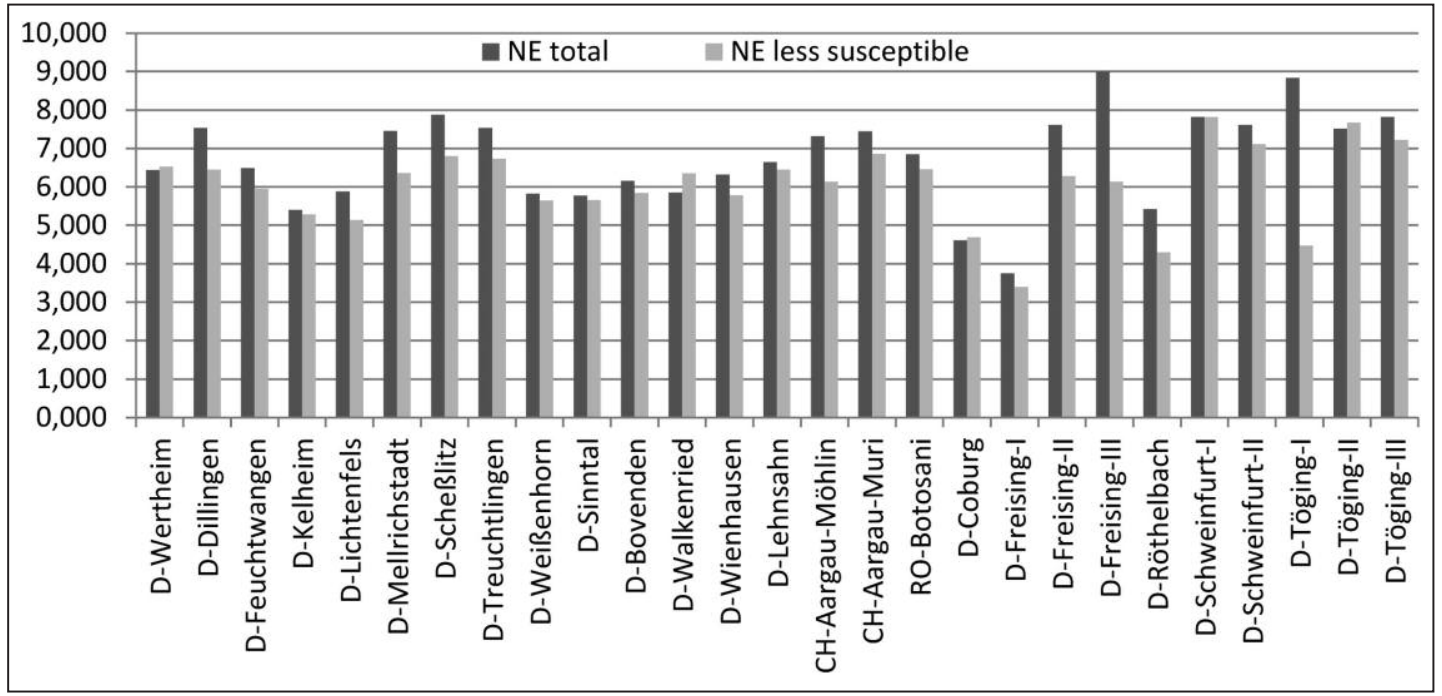

Figure 5. - Genetic diversity $\left(\mathrm{N}_{\mathrm{E}}\right)$ for all trees per population $\left(\mathrm{N}_{\mathrm{E}}\right.$ total) compared to the less susceptible trees per population $\left(\mathrm{N}_{\mathrm{E}}\right.$ less susceptible). 
in the groups of less susceptible trees. Here in 12 populations the $\mathrm{F}_{\mathrm{IS}}$-values were higher and in 14 populations lower for the groups of less susceptible trees compared to the groups of susceptible trees. Relatedness of individuals ( $r$ ) were compared for the two groups (susceptible vs. less susceptible) within populations. The values

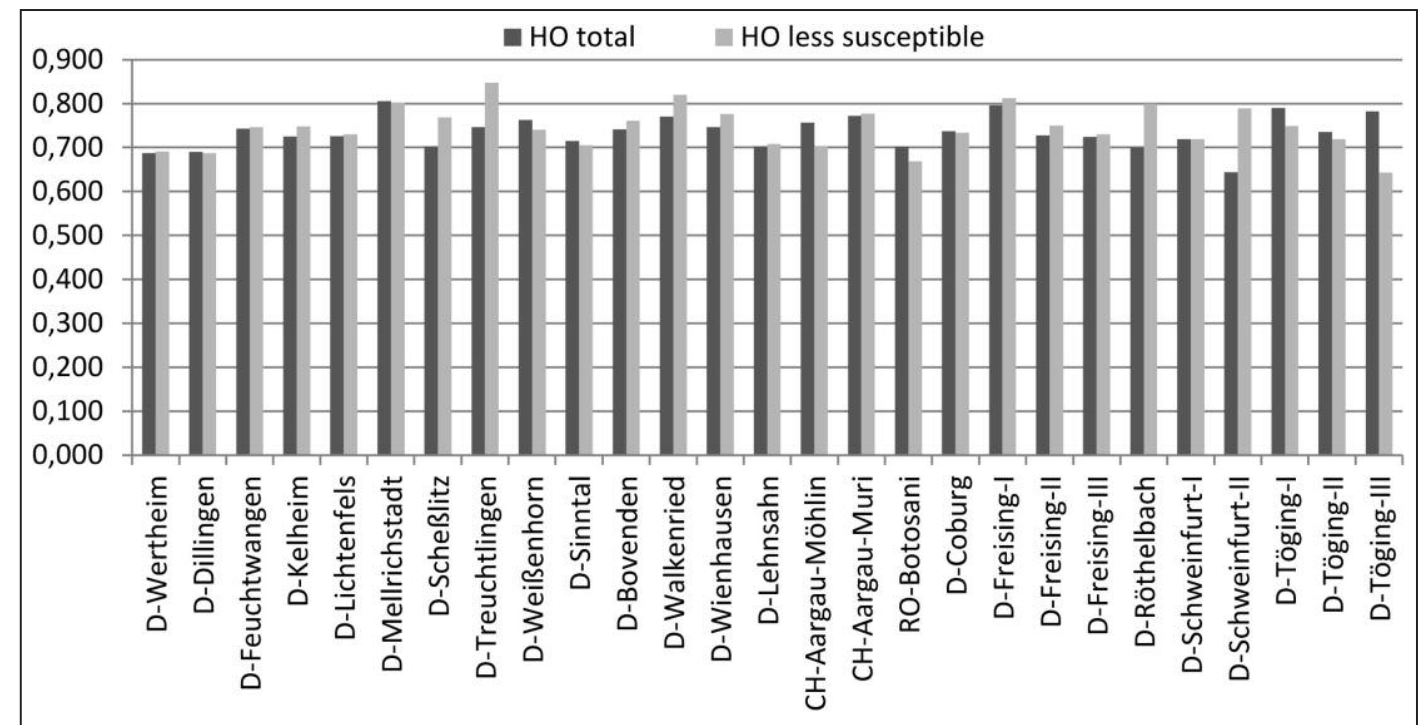

Figure 6. - Observed heterozygosity $\left(\mathrm{H}_{\mathrm{O}}\right)$ for all trees per population $\left(\mathrm{H}_{\mathrm{O}}\right.$ total $)$ compared to the less susceptible trees per population $\left(\mathrm{H}_{\mathrm{O}}\right.$ less susceptible).

Table 4. - Diversity parameters, relatedness, NEI's genetic distance and pairwise $\mathrm{F}_{\mathrm{ST}}$-values for susceptible and less susceptible trees within populations of the provenance trial and the permanent study plots based on nuclear microsatellites.

\begin{tabular}{|c|c|c|c|c|c|c|c|c|c|c|c|c|c|c|c|c|}
\hline \multirow{2}{*}{ Population } & \multicolumn{2}{|c|}{$\mathbf{n}$} & \multicolumn{2}{|c|}{$\mathbf{N}_{\mathrm{E}}$} & \multicolumn{2}{|c|}{$\mathbf{A}_{4}$} & \multicolumn{2}{|c|}{$\mathrm{H}_{0}$} & \multicolumn{2}{|c|}{$\mathbf{H}_{\mathrm{L}}$} & \multicolumn{2}{|c|}{$F_{1 S}$} & \multicolumn{2}{|c|}{$\mathbf{r}$} & \multirow{2}{*}{ d } & \multirow{2}{*}{$\mathrm{F}_{\mathrm{ST}}$} \\
\hline & $s$ & Is & $\mathrm{s}$ & Is & $\mathrm{s}$ & Is & $s$ & Is & $\mathrm{s}$ & Is & $s$ & Is & $\mathrm{s}$ & ls & & \\
\hline D-Wertheim & 19 & 19 & 5,29 & 6.53 & 4,49 & 5,00 & 0,684 & 0,691 & 0,734 & 0.800 & 0.095 & 0.163 & 0.177 & 0,077 & 0.15 & $0.01 .5 \mathrm{r}$ \\
\hline D-Dillingen & 17 & 20 & 6.57 & 6.45 & 4.93 & 5.11 & $0.69 \mathrm{~J}$ & 0.687 & 0.744 & 0.780 & 0.101 & 0,145 & 0.131 & 0.076 & 0.13 & $0.006:$ \\
\hline D-f'euchtwangen & 22 & 11 & 5,96 & 5.95 & 4.95 & 5.11 & 0,742 & 0.747 & 0.789 & 0,784 & 0.083 & 0,096 & 0.093 & 0,050 & 0.18 & $0.006 \mathrm{~ns}$ \\
\hline D-Kelheim & 20 & 24 & 5,12 & 5.29 & 4,64 & 4,59 & 0,696 & 0,748 & 0,764 & 0.769 & 0.316 & 0.049 & 0,179 & 0.187 & 0.06 & $-0,008 \mathrm{ris}$ \\
\hline D-l ichtenfels & 24 & 16 & 5,93 & 5.14 & 4,84 & 4.58 & 0,724 & 0.730 & 0.793 & 0.753 & 0,109 & 0063 & 0,093 & 0.146 & 0.09 & -0.003114 \\
\hline D-Mellrichstadt & 14 & 17 & 6,83 & 6.37 & 5.29 & 5.07 & 0,810 & 0.801 & 0.831 & 0.823 & 0,062 & 0.057 & 0,047 & 0.063 & 0.22 & 0,006115 \\
\hline D-Scheßlilz & 19 & 17 & 7,17 & 6.81 & 5.31 & 5,23 & 0,643 & 0,769 & 0,807 & 0.795 & 0.229 & 0.063 & 0,038 & 0,048 & 0.16 & 0,004115 \\
\hline D-Treuchtlingen & 29 & 9 & 7,02 & 6.73 & 5,18 & 5.49 & 0,715 & 0.847 & 0.825 & 0.809 & 0,151 & 0.011 & 0.042 & 0,017 & 0,14 & $-0.012 \mathrm{~ns}$ \\
\hline D-WeiBenhorn & 20 & 22 & 5,38 & 5.65 & 4.90 & 4,87 & 0,788 & 0,741 & 0,805 & 0,796 & 0.047 & 0,092 & 0.107 & 0,094 & 0.11 & $-0,0001 \mathrm{IIS}$ \\
\hline D-Sinntal & 1,3 & 22 & 4.74 & 5.66 & 4.60 & 4.74 & $0.73 \mathrm{~J}$ & 0.706 & 0.757 & 0,749 & 0.075 & 0,081 & 0.137 & 0.146 & 0.18 & $0.020 \mathrm{~ns}$ \\
\hline D-Bovender & 20 & 15 & 5,92 & 5.84 & 4.94 & 5,00 & 0,731 & 0.761 & 0.776 & 0,773 & 0.078 & 0.05 & 0.111 & 0,092 & 0.08 & $-0.008 \mathrm{~ns}$ \\
\hline D-Walkenried & 23 & 16 & 4,99 & 6.35 & 4,49 & 5,13 & 0,737 & 0,820 & 0,772 & 0.810 & 0.068 & 002 & 0.150 & 0,082 & 0.11 & Sוזו \\
\hline D-Wienhausen & 23 & 16 & 6,01 & 5,79 & 4,88 & 4.96 & 0,726 & 0.777 & 0.811 & 0.805 & 0,128 & 0.068 & 0,070 & 0.071 & 0.11 & -0.00611 .4 \\
\hline D-Lehnsathn & 15 & 23 & 606 & 6,45 & 4.96 & 5.08 & 0,685 & 0,708 & 0.788 & 0,814 & 0,166 & 0,152 & 0,069 & 0.050 & 0.12 & $-0.005 \mathrm{~ns}$ \\
\hline $\mathrm{CH}-\mathrm{Aa}$ & 21 & 19 & & 6.1 & & & & & & & 0,03 & & & & 0. & $\ln$ \\
\hline Cl1-Aargau-Muri & 23 & 20 & 6,60 & 6.86 & 5,07 & 5.11 & 0,768 & $0, \pi$ & 0.780 & 0,763 & 0,037 & 0,009 & 0.119 & 0,136 & 0.09 & $0.000 \mathrm{~ns}$ \\
\hline RO-Botosani & 11 & 17 & 5,99 & 6.46 & 5.05 & 5,12 & 0,750 & 0,668 & 0,762 & 0,794 & 0.064 & 0,189 & 0.141 & 0,093 & 0.14 & $-0,0007 \mathrm{IIS}$ \\
\hline D-Coburg & 20 & 79 & 4,18 & 4.69 & 4.29 & 4.40 & $0.75 \mathrm{~J}$ & 0.734 & 0.705 & 0.721 & -0.037 & $-0,012$ & 0.237 & 0.222 & 0.04 & $-0.002 n s$ \\
\hline D-Freising-I & 27 & 10 & 3.66 & $3,4\rfloor$ & 3,59 & 3,63 & 0.789 & 0,813 & 0,647 & 0.636 & -0.201 & -0.229 & 0.121 & $0.140^{\circ}$ & 0.09 & 0,020115 \\
\hline D-Freising-Il & 86 & 8 & 7,32 & 0.29 & 5.15 & 5,50 & 0,722 & 0,750 & 0,800 & 0.803 & 0.103 & 0.132 & 0.044 & 0,056 & 0.18 & $0,00211 \mathrm{~s}$ \\
\hline D-Frcising-III & 61 & 8 & 9,04 & 6,14 & 5.52 & 5.39 & & & & & 156 & & & & 0.24 & $0,003 \mathrm{~ns}$ \\
\hline D-Röthelbach & 37 & 8 & 5,40 & 4.30 & 4,76 & 4,62 & 0,689 & 0,749 & 0.783 & 0.742 & 0,134 & 0.066 & 0,187 & 0.029 & 0.18 & 0,003115 \\
\hline D-Schweinfurt-Il & 4 & $2]$ & 4,60 & 7.12 & 5.50 & 5.28 & 0.750 & 0.643 & 0.723 & 0,786 & 0.106 & 0,206 & 0.009 & 0.036 & 0.39 & $0.010_{\mathrm{ns}}$ \\
\hline 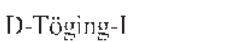 & 13 & 5 & $8,2]$ & 4.47 & 5,91 & 5,13 & 0,774 & 0,800 & 0,841 & 0.758 & 0,12 & 0.055 & 0.407 & 0,388 & 0.43 & $0.006 \mathrm{~ns}$ \\
\hline L-Töging-II & 19 & 30 & 5,08 & 7.68 & 4.64 & 5,40 & 0,7015 & 0,753 & 0,730 & 0,830 & 0,061 & 0,109 & 0,091 & 0,009 & 0.20 & $0,03]^{* * *}$ \\
\hline D-T'öging-III & 7 & 13 & 5.82 & 7.22 & 5.34 & 5.40 & 0.768 & 0.789 & 0.789 & 0.794 & 0.107 & 0,047 & 0.012 & 0.021 & 0.33 & $0.0099_{\mathrm{ns}}$ \\
\hline
\end{tabular}

$\mathrm{n}$, number of individuals; $\mathrm{N}_{\mathrm{E}}$, genetic diversity; $\mathrm{A}_{4}$, allelic richness after rarefaction (rarefaction size $=4$ ); $\mathrm{H}_{\mathrm{O}}$, observed heterozygosity; $\mathrm{H}_{\mathrm{E}}$, expected heterozygosity; $\mathrm{F}_{\mathrm{IS}}$, fixation index; $r$, relatedness of individuals within groups; $d$, Nei's genetic distance; $\mathrm{F}_{\mathrm{ST}}$, pairwise $\mathrm{F}_{\mathrm{ST}}$-value; $\mathrm{s}$, susceptible trees; ls, less susceptible trees; significance levels for pairwise $\mathrm{F}_{\mathrm{ST}}$-values: ns, non-significant; $* \mathrm{p}<0.05 ;{ }^{* *} \mathrm{p}<0.01$; all other tested values were non-significant and therefore not mentioned in the table. 
ranged from 0.009 (D-Schweinfurt-II) to 0.407 (DTöging-I) for the groups of susceptible trees and from 0.009 (D-Töging-II) to 0.388 (D-Töging-I). In 13 populations the values were higher and in 13 populations they were lower in the groups of less susceptible trees compared to the groups of susceptible ones. In single cases differences between susceptible and less susceptible groups were high, but no significant differences were found for any of the values.

Genetic distances (NEI, 1972) between the two groups in each population ranged from 0.06 (D-Kelheim) to 0.22 (D-Mellrichstadt) for provenances of the provenance trial. Within the four provenances D-Kelheim, D-Lichtenfels, D-Bovenden, CH-Aargau-Muri the genetic distance between groups was low. For the other provenances it was at medium level. For the permanent study plots the range of genetic distances was larger, with values between 0.04 (D-Coburg) and 0.43 (D-Töging-I). Pairwise $\mathrm{F}_{\mathrm{ST}}$-values ranged from -0.012 (D-Treuchtlingen) to 0.020 (D-Sinntal) for the provenance trial and from -0.002 (D-Coburg) to 0.031 (D-Töging-II) for the permanent study plots. In single cases differences between susceptible and less susceptible groups were high, but only two were significant (D-Dillingen, D-Töging-II, Table 4).

When pooling all susceptible and all less susceptible individuals into two groups slight but non-significant differences were found for $\mathrm{A}(4.9$ vs 5.0$), \mathrm{H}_{\mathrm{O}}(0.727 \mathrm{vs}$ $0.741), \mathrm{H}_{\mathrm{E}}(0.800$ vs 0.798$), \mathrm{F}_{\mathrm{IS}}(0.092$ vs 0.072$)$ and $\mathrm{F}_{\mathrm{ST}}$ (0.066 vs 0.063 ) (data not shown).

\section{Discussion}

\section{Genetic variation of ash populations}

Our investigation shows high genetic variation within and high genetic differentiation between ash populations. Differentiation was substantially higher than for other tree species as Fagus sylvatica (for 10 German populations Nei's genetic distance was between 0.05 and 0.21 based on ten nuclear microsatellite markers, own unpublished results) and Prunus avium (DE RoGATIS et al., 2013). High genetic variation within stands was found for ash in similar studies (e.g. in Italy FERRAZZINI et al., 2007). Pairwise population differentiation in the present study $\left(\mathrm{F}_{\mathrm{ST}}=0.005-0.145\right)$ was slightly higher compared to Italian $\left(\mathrm{F}_{\mathrm{ST}}=0.001-0.104\right.$, FERRAZZINI et al., $2007)$ and British ash populations $\left(\mathrm{F}_{\mathrm{ST}}=0.008-0.111\right.$, SUTHERLAND et al., 2010). However overall differentiation $\left(\mathrm{F}_{\mathrm{ST}}=0.046\right)$ was lower compared to populations from Bulgaria $\left(\mathrm{F}_{\mathrm{ST}}=0.087\right.$, HEUERTZ et al., 2001). $\mathrm{F}_{\mathrm{IS}^{-}}$ values $\left(\mathrm{F}_{\mathrm{IS}}=0.108\right.$ and $\mathrm{F}_{\mathrm{IS}}=0.112$, overall and for German populations, respectively) were higher compared to other studies (e.g. $\mathrm{F}_{\text {IS }}=0.030$ in HEUERTZ et al., 2004b).

Ash is a species which often regenerates naturally, but which has also been introduced artificially by planting. For the investigated populations we have no information on the history or the intensity of human impact. Both factors, natural and artificial regeneration, can influence genetic structures especially on a microgeographic scale. In addition recolonization history and gene flow by pollen and seed are important factors influ- encing the genetic variation pattern of ash. Strong differentiation among populations was found using chloroplast markers $\left(\mathrm{G}_{\mathrm{ST}}=0.89\right)$ reflecting low mixing of recolonizing lineages in Europe, which indicates that historical effective seed dispersal occurred mainly over short distances (HEUERTz et al., 2004a). Therefore pollen dispersal might be more effective, since the dispersion of pollen by wind is typical for $F$. excelsior. Nevertheless the data on pollen dispersal is contradictory. Very limited pollen dispersal has been reported in $F$. excelsior $50 \%$ and $95 \%$ of pollen dispersed at less than $10 \mathrm{~m}$ and $50 \mathrm{~m}$, respectively, (AltMAN and DitTMER, 1964 in HEUERTZ et al., 2001). DougLAS (2006) also mentioned that pollen flow and seed dispersal in ash is generally restricted within the stand. These findings could explain the high genetic variation observed within populations and also the high genetic differentiation between populations found in the present study. Moreover, the movement of reproductive material during artificial regeneration with often differing genetic variation depending e.g. on the number of seed trees might also play a role. However a study in Scotland indicated that pollen gene flow into each of three fragmented populations was extensive (46-95\%) and that the pollen dispersal had two components: a very localized and restricted one and a second one stretching over long distances with dispersal occurring over several kilometers (BACLES et al., 2005). Effective dispersal distances (average $328 \mathrm{~m}$ ) were greater for fragmented populations than values reported for contiguous populations (BACLES et al., 2005).

No clear geographic pattern was found for the analysed populations based on nuclear microsatellites using allele frequencies. Each population seems to be genetically unique. However, certain characteristics were detected, especially regarding the number of rare alleles, which suggest large scale genetic differences. The two Slovenian populations and the region south of the Alps adjacent to Slovenia (AUT-Karnerviertel) showed the lowest values of rare alleles. This is a strong indication that different genetic structures exist in the south of the Alps compared to populations from the north.

The more conservative chloroplast markers suggest an east-west division of ash in Bavaria. Thereby the eastern part is clearly more heterogeneous. The altogether lower variation found in chloroplast markers conforms to findings within other studies for ash described in the literature (HEUERTz et al., 2004a; HEBEL et al., 2006b). However, based on chloroplast markers, differences between the populations were found in the present study. Several populations were monomorphic regarding the chloroplast markers, i.e. the variation introduced via the maternal line was low. Other populations showed remarkably high values for the variation in chloroplast types. Historical contact of different chloroplast lineages (ash survived the last glacial maximum in Iberia, Italy, the eastern Alps and the Balkan Peninsula, Heuertz et al., 2004a) could be an explanation for the high chloroplast variation in populations from south-eastern Bavaria D-Töging-I and II, D-Freising-II and one neighboring population from Austria (AUT-Ettenau). Such high variation in the region of south-eastern Bavaria is 
congruent with earlier findings by HEUERTZ et al. (2004a) who have detected four chloroplast types in this region. Interestingly in the same region (south-eastern Bavaria) sycamore maple (Acer pseudoplatanus) showed a higher chloroplast variation compared to other regions in Germany (Konnert, unpublished results). Even for silver fir (Abies alba) this region was a contact zone for western and eastern recolonization routes (KONNERT and BERGMANN, 1995). For the population D-Scheßlitz from northern Bavaria artificial introduction might be a more likely reason for the observed high haploid diversity.

Consequently the present research showed that ash populations from southern Germany were genetically very different. However, most of the studied populations displayed symptoms of ash dieback, although in different intensity, except for population D-Schweinfurt-I, where ash dieback has not been detected in the year of assessment. Nevertheless, resistance on the population level seems rather unlikely, because population DSchweinfurt-I did not reveal any specifics based on the analysed markers that could explain such resistance. More likely is that $H$. fraxineus has not arrived in that population. From own field observations and studies of clonal trials (e.g. McKINNEY et al., 2011a) the resistance against ash dieback seems to be on an individual rather than on a population level.

\section{Genetic differences between susceptible and less susceptible trees}

For the provenance trial and the permanent study plots differences between susceptible and less susceptible trees within each of the populations were detected. In some cases the genetic distance can be considered medium to high with significant $\mathrm{F}_{\mathrm{ST}}$-values in two populations (D-Dillingen, D-Töging-II, Table 4). With regard to genetic variation and diversity between susceptible and less susceptible trees the trend was not consistent. However, genetic variation (number of alleles and genetic diversity) decreased when comparing all trees to the less susceptible ones within each population. According to theoretical predictions, genetically less diverse populations have lower adaptability (Young et al., 1996; WILLI et al., 2006).

Our results slightly indicate that heterozygotic individuals might be able to withstand ash dieback in a better way in comparison to homozygotic individuals, because the degree of heterozygotic individuals (observed heterozygosity, $\mathrm{H}_{\mathrm{O}}$ ) was higher in the less susceptible groups compared to the susceptible groups. This means a higher variability on the individual level for heterozygotic individuals and those might therefor have higher plasticity and reaction capacity against the disease. NAmkoong et al. (1998) and TESSIER DU Cros et al. (1999) earlier suggested that heterozygotic individuals could be more resistant to environmental stresses.

A general trend for higher relatedness of individuals within the groups of less susceptible trees was not found. Both groups exhibited strong and weak relationship between individuals and some populations showed high, others low genetic difference between the two groups.
The remaining level of genetic diversity within the group of less susceptible individuals gives reason for hope that it will be possible to select diverse individuals and merge them into a breeding population. This is important for breeding programs to ensure a wide genetic base, particularly since analyses based on microsatellites revealed genetic variation in $H$. fraxineus populations (BENGTSSON et al., 2012; Fussi et al., 2012; GHERGHeL et al., 2013) and genotype dependent differences in the pathogen - tree interaction might be expected.

At the moment contrasting opinions on the genetic control of resistance against ash dieback exist. Within clonal trials in Sweden (STENER, 2013) and Denmark (MCKINNEY et al., 2011a; KJÆR et al., 2011) strong genetic control of resistance against ash dieback was found. This was based upon the observation of artificially or naturally infected trees in common garden experiments that have shown clonal differences in infection intensity (McKINNEY et al., 2011b). On the other hand doubts exist about the degree of resistance of individuals without symptoms (ENDERLE et al., 2013), since the mechanisms preventing those individuals from becoming infected is still largely unknown. Nevertheless it is of utmost importance to identify and preserve less susceptible trees for gene conservation and future breeding programs. Results of the present study have shown that within the group of less susceptible trees a wide genetic base exists whereupon a future breeding program can be built. Detailed recommendations for future germplasm collection can be found in PAUTASso et al. (2013). Different management procedures of affected common ash stands, from clear-cutting to removal of single heavy diseased trees, are already ongoing. As an example SANDER (2014) describes a scenario in one forest district and recommends that less affected individuals should not be removed, which is important for the species in order to maintain the genetic potential for future seed production and regeneration.

\section{Acknowledgements}

The authors wish to thank HoJKA KRAIGHER and BERTHOLD HEINZE for providing ash samples. We also thank the staff of the Bavarian State Institute of Forestry for assistance with sampling and damage recording of ash shoot disease and the laboratory staff of ASP for sampling and genetic analysis. Additional thanks go to WOLFHARD RUETZ for language corrections and for reading the manuscript critically. We also want to thank two anonymous reviewers for their valuable suggestions. The current study was financially supported by the Bavarian State Ministry for Food, Agriculture and Forestry (KLIP1-project).

\section{References}

Brown, A. H. D. and B. S. WeIR (1983): Measuring genetic variability in plant populations. In: TANSKLEY, S. D., ORTON, T. J. (ed.). Isoenzymes in plant genetics and breeding. Part A. Elsevier, Amsterdam, pp. 219-229.

BACles, C. F. E. and R. A. EnNos (2008): Paternity analysis of pollen mediated gene flow for Fraxinus excelsior 
L. in a chronically fragmented landscape. Heredity 101: 368-380.

Bacles, C. F. E., J. Burczyk, A. J. Lowe and R. A. Ennos (2005): Historical and contemporary mating patterns in remnant populations of the forest tree Fraxinus excelsior L. Evolution 59: 979-990.

Bakys, R., R. VAsaitis, P. Barklund, I.-M. Thomsen and J. STENLID (2009a): Occurrence and pathogenicity of fungi in necrotic and non-symptomatic shoots of declining common ash (Fraxinus excelsior) in Sweden. Eur J Forest Res 128: 51-60.

BAKYS, R., R. VASAITIS, P. BARKLUnd, K. IHRMARK and J. STENLID (2009b): Investigations concerning the role of Chalara fraxinea in declining Fraxinus excelsior. Plant Path 58: 284-292.

BARAL, H. O., V. Queloz and T. Hosoya (2014): Hymenoscyphus fraxineus, the correct scientific name for the fungus causing ash dieback in Europe. IMA Fungus 5: 79-80

Bengtsson, S. B. K., R. VAsaitis, T. Kirisits, H. Solheim and J. STENLID (2012): Population structure of Hyme noscyphus pseudoalbidus and its genetic relationship to Hymenoscyphus albidus. Fungal Ecol. 5: 147-153.

Brachet, S. M., F. Jubier, M. Richard, B. Jung-Muller and N. FRASCARIA-LACOSTE (1999): Rapid identification of microsatellite loci using 59 anchored PCR in the common ash Fraxinus excelsior. Molecular Ecology 8: 160-163.

De Rogatis, A., D. Ferrazzini, F. Ducci, S. Guerri, S. Carnevale and P. Belletti (2013): Genetic variation in Italian wild cherry (Prunus avium L.) as characterized by nSSR markers. Forestry 86 (3): 391-400. doi:10.1093/forestry/cpt009

Douglas, G. (2006): Genetic improvement of ash (Fraxinus excelsior L.): Abstract of Workshop on Genetics, 18-22 April 2006, Leuven-Belgium; 7 pp.

Dumolin, S., B. Demesure and R. J. Petit (1995): Inheritance of chloroplast and mitochondrial genomes in pedunculate oak investigated with an efficient PCR method. Theor. Appl. Genet. 91: 1253-1256

Enderle, R., F. Peters, A. NaKou and B. Metzler (2013): Temporal development of ash dieback symptoms and spatial distribution of collar rots in a provenance trial of Fraxinus excelsior. Eur J Forest Res 132: 865-876. DOI 10.1007/s10342-013-0717-y

Evanno, G., S. Regnaut and J. Goudet (2005): Detecting the number of clusters of individuals using the software structure: a simulation study. Mol Ecol. 14: 2611-2620.

Falush, D., M. Stephens and J. K. Pritchard (2003): Inference of population structure using multilocus genotype data: linked loci and correlated allele frequencies. Genetics 164: 1567-1587.

FELSENSTEIN, J. (2004): PHYLIP (Phylogeny Inference Package) version 3.6. Distributed D the author. Department of Genome Sciences, University of Washington, Seattle.

Fernández-Manjarrés, J. F., P. R. GÉrard, J. Dufour, C. RAQUiN and N. Frascaria-Lacoste (2006): Differential patterns of morphological and molecular hybridization between Fraxinus excelsior L. and Fraxinus angus tifolia Vahl (Oleaceae) in eastern and western France. Mol Ecol 15: 3245-3257.

Ferrazzini, D., I. Monteleone and P. Belletti (2007): Genetic variability and divergence among Italian populations of common ash (Fraxinus excelsior L.). Ann. For. Sci. 64: 159-168.

Fussi, B., E. Cremer and M. Konnert (2012): Neue Möglichkeiten zur Diagnose des Pilzes in Eschengewebe. AFZ/Der Wald 24: 13-15.
Gérard, P. R., M. Temunovic, J. SAnnier, B. Bertolino, J. Dufour, N. Frascaria-Lacoste and J. F. FernándezMANJARRÉS (2013): Chilled but not frosty: understanding the role of climate in the hybridization between the Mediterranean Fraxinus angustifolia Vahl and the temperate Fraxinus excelsior L. (Oleaceae) ash trees. J Biogeogr 40: 835-846.

Gherghel, F., B. Fussi, K. Donges, M. Haustein, K. M. Jakob, K. Mueller, B. Piskur, T. Hauptman, H. D. Lenz, M. Konnert, G. Kost and K. H. Rexer (2013): Early detection of Chalara fraxinea in planta tissues: the development of seven diagnostic microsatellite markers. For Path doi: 10.1111/efp.12078.

GOUDET, J. (1995): FSTAT (version 1.2): a computer program to calculate F-statistics. Journal of Heredity 86: $485-486$.

Gömöry, D., L. PAule, D. Krajmerová, I. RomsákovÁ and J. PIECKA (2012): Gene exchange across a postglacial contact zone in Fraxinus excelsior L. Silvae Genetica 61 18-27.

Hartu, D. L. and A. G. Clark (1997): Principles of Population Genetics ( $3^{\text {rd }}$ edn). Sinauer Associates, Sunderland MA.

Hebel, I., E. Aldinger, R. Hass, M. Karopka, A. BogenRIEDER and A. DounAVI (2006a): Untersuchungen zur Pollenverbreitung und Pollenkontamination in einer Eschen-Samenplantage (Fraxinus excelsior L.). Allg. Forst- u. Jagdzeitung 178 (2/3): 44-49.

HeBel, I., R. HASs and A. DounAvi (2006b): Genetic variation of common ash (Fraxinus excelsior L.) populations from provenance regions in southern Germany by using nuclear and chloroplast microsatellites. Silvae Genetica 55 (1): 38-44.

Heuertz, M., S. Carnevale, S. Fineschi, F. Sebastiani, J. F. Hausman, L. Paule and G. G. Vendramin (2006): Chloroplast DNA phylogeography of European ashes, Fraxinus sp. (Oleaceae): roles of hybridization and life history traits. Molecular Ecology, 15, 2131-2140.

Heuertz, M., S. FinesChI and M. ANZIDEI et al. (2004a): Chloroplast DNA variation and postglacial recolonization of common ash (Fraxinus excelsior L.) in Europe. Molecular Ecology 13: 3437-3452.

Heuertz, M., J. F. Hausman and O. J. Hardy et al. (2004b): Nuclear microsatellites reveal contrasting patterns of genetic structure between western and southeastern European populations of the common ash (Fraxinus excelsior L.). Evolution, 58, 976-988.

Heuertz, M., X. Vekemans, J. F. Hausman, M. Palada and O. L. HARDY (2003): Estimating seed vs. pollen dispersal from spatial genetic structure in the common ash. Molecular Ecology, 12, 2483-2495.

Heuertz, M., J. F. Hausman, I. Tsvetkov, N. FrascariaLACOSTE and X. VEKEMANS (2001): Assessment of genetic structure with and among Bulgarian populations of the common ash (Fraxinus excelsior L.). Molecular Ecology 10: $1615-1623$.

Höltken, A. M., J. TÄHtinen and A. Pappinen (2003): Effects of discontinuous marginal habitats on the genetic structure of common ash (Fraxinus excelsior L.). Silvae Genetica 52: 206-212.

KJæR, E. D., L. V. MCKinney, L. R. Delsen, L. N. Hansen and J. K. HANSEN (2011): Adaptive potential of ash (Fraxinus excelsior) populations against the novel emerging pathogen Hymenoscyphus pseudoalbidus. Evol App 5: 219-228.

KöLLING, C. (2007): Klimahüllen für 27 Waldbaumarten. AFZ-Der Wald 23: 1242-1245. 
KöLling, C. and H. WALEnTowski (2002): Die Rolle der Esche (Fraxinus excelsior) in einheimischen Waldgesellschaften. Beiträge zu Esche. Berichte aus der Bayerischen Landesanstalt für Wald- und Forstwirtschaft 34: $6-20$.

KonNeRT, M. and F. BERGMANn (1995): The geographical distribution of genetic variation of silver fir (Abies alba, Pinaceae) in relation to its migration history. Pl. Syst. Evol. 196: 19-30.

Kowalski, T. and O. HoldenRIEDER (2009): The teleomorph of Chalara fraxinea, the causal agent of ash Dieback. For Path 39: 304-308.

Lefort, F., S. BracdT, N. Frascaria-Lacoste, K. J. EDWARDS and G. C. Douglas (1999): Identification and characterization of microsatellite loci in ash (Fraxinus excelsior L.) and their conservation in the Olives family. Molecular Ecology 8: 1088-1090.

Lenz, H., B. Pöllner, L. Strasser, A. Nannig and R. Petercord (2012a): Entwicklung des Eschentriebsterbens. LWF aktuell 88: 14-16.

Lenz, H., L. Strasser, M. BAumanN and U. Baier (2012b): Boniturschlüssel zur Einstufung der Vitalität von Alteschen. AFZ-Der Wald 3: 18-19.

McKinney, L. V., L. R. Nielsen, J. K. Hansen and E. D. KJÆR (2011a): Presence of natural genetic resistance in Fraxinus excelsior (Oleraceae) to Chalara fraxinea (Ascomycota): an emerging infectious disease. Heredity 106: 788-797.

McKinney, L.V., I. M. Thomsen, E. D. KJer and L. R. NiELSEN (2011b): Genetic resistance to Hymenoscyphus pseudoalbidus limits fungal growth and symptom occurrence in Fraxinus excelsior. For Path 42: 69-74.

Metzler, B., R. Enderle, M. Karopka, K. Töpfner and E. Aldinger (2013): Entwicklung des Eschentriebsterbens in einem Herkunftsversuch an verschiedenen Standorten in Süddeutschland. Allg. Forst- u. J.-Ztg 183: $168-108$.

Morand, M. E., S. Brachet, P. Rossignol, J. Dufour and N. FRASCARIA-LACOSTE (2002): A generalized heterozygote deficiency assessed with microsatellites in French common ash populations. Mol Ecol, 11: 377-385

NAmKoONG, G. (1998): Forest Genetics and Conservation in Europe. In: Turok, J., Palmberg-Lerche, C., SkrøpPA, T., OuÉDraogo, A. S. (Eds.), Conservation of forest genetic resources in Europe, International Plant for Genetic Resources Institute, Rome, 1998, pp. 3-10.

NEI, M. (1972): Genetic distance between populations. Am Nat. 106: 283-292.

Pautasso, M., G. Aas, V. Queloz and O. Holdenrieder (2013): European ash (Fraxinus excelsior) dieback - A conservation biology challenge. Biological Conservation 158: 37-49.

Peakall, R. and P. E. Smouse (2006): GenAlEx 6: genetic analysis in Excel. Population genetic software for teaching and research. Mol Ecol Notes 6: 288-295.

Pliura, A., V. Lygis, V. Suchockas and E. BartKevicius (2011): Performance of twenty four European Fraxinus excelsior populations in three Lithuanian progeny trials with a special emphasis on resistance to Chalara fraxinea. Balt For 17 (1): 17-34.

PUKACKI, P.-M. and K. PRZYDL (2005): Frost injury as a possible inciting factor in bud and shoot necroses of Fraxinus excelsior L. J Phytopathol 153: 512-516.

R CORE TEAM (2013): R: A language and environment for statistical computing. R Foundation for Statistical Computing, Vienna, Austria. ISBN 3-900051-07-0, URL http://www.R-project.org/.
KLEINSCHMIT, J., F. LÜCK, H.-M. RAU and W. RUETZ (2002): Ergebnisse eines Eschen-Herkunftsversuchs. Forst und Holz 6: 166-172.

Queller, D. C. and K. F. Goodnight (1989): Estimating relatedness using genetic markers. Evolution 43: 258-275.

Queloz, V., C. Gruenig, R. Berndt, T. Kowalski, T.-N. Sieber and O. HoldenRIEDER (2011): Cryptic speciation in Hymenoscyphus albidus. For Path 41: 133-142.

SANDER, C. (2014): Erfahrungen zum Eschentriebsterben in der Oberförsterei Gadow. AFZ-Der Wald 1: 35.

Schneider, S., J. KuefFer, D. Roessli and L. Excoffier (1997): A software for population genetic data analysis, University of Geneva, Switzerland: Genetics and Biometry Laboratory.

SteneR, L. G. (2013): Clonal differences in susceptibility to the dieback of Fraxinus excelsior in southern Sweden, Scandinavian Journal of Forest Research, 28: 3, 205-216.

Sutherland, B. G., A. Belaj, S. Nier, J. E. Cotrell, S. P. VAughan, J. HuberT and K. Russell (2010): Molecular biodiversity and population structure in common ash (Fraxinus excelsior L.) in Britain: implications for conservation. Mol Ecol 19: 2196-2211.

Tessier du Cros, E., C. MÀtyàs and H. Kriebel (1999): Contribution of genetics to the sustained management of global forest resources - Conclusions and recommendations. In: MÀtyàs, C. (Ed.), Forest genetics and sustainability, Forestry Sciences, Vol. 63, Kluwer Academic Publishers, Dordrecht, pp. 281-287.

Thomasset, M., J. F. Fernández-Manjarkés, G. C. Douglas, P. Bertolino, N. Frascaria-lacoste and T. R. Hodkinson (2013): Assignment testing reveals multiple introduced source populations including potential ash hybrids (Fraxinus excelsior $\times F$. angustifolia) in Ireland. Eur J For Res 132: 195-209.

Thomasset, M., T. R. Hodkinson, G. Restoux, N. FrasCARIA-Lacoste, G. C. Douglas and J. F. FernándezMANJARRÉS (2014): Thank you for not flowering: conservation genetics and gene flow analysis of native and non-native populations of Fraxinus (Oleaceae) in Ireland. Heredity 112: 596-606.

VASAITIS et al., SNS: Nordic Forest Research Co-operation Committee (2013): New light on causes of ash decline. News and Views, Scandinavian Journal of Forest Research, 28:6, 608-611, DOI: 10.1080/02827581. 2013.822159 .

WeIR, B. S. and C. C. Cockerham (1984): Estimating F-statistics for the analysis of population structure. Evolution 38: 1358-1370.

WEISING, K. and R. C. GARDNER (1999): A set of conserved PCR primers for the analysis of simple sequence repeat polymorphisms in chloroplast genomes of dicotyledonous angiosperms. Genome 42: 9-19.

Willi, Y., J. VAN BuskiRK and A. A. Hoffmann (2006): Limits to the adaptive potential of small populations. Annual Review of Ecology, Evolution and Systematics 37, 433-458.

WoODWARD, S. and E. BoA (2012): Ash dieback in the UK: a wake-up call. Mol Plant Path 14 (9): 856-860.

Young, A., T. BOYLE and T. Brown (1996): The population genetic consequences of habitat fragmentation for plants. Trends in Ecology and Evolution, 11, 413-418.

ZHAO, Y., T. HosoYa, H. BARAL, K. HosaKa and K. KAKISHIMA (2012): Hymenoscyphus pseudoalbidus, the correct name for Lambertella albida reported from Japan. Mycotaxon 122: 25-41. 